1 Post-print

2

3 Eva, E., Malusà, M. G., \& Solarino, S. (2020)

4

5 Seismotectonics at the Transition Between

6 Opposite-Dipping Slabs (Western Alpine Region)

7

8 Tectonics, 39(9), e2020TC006086

10 https://doi.org/10.1029/2020TC006086 


\title{
Seismotectonics at the transition between opposite-dipping slabs (western Alpine region)
}

\author{
E. Eva ${ }^{1}$, M.G. Malusà ${ }^{2,1}$, and S. Solarino ${ }^{1}$
}

\author{
${ }^{1}$ Istituto Nazionale di Geofisica e Vulcanologia, Osservatorio Nazionale Terremoti, c/o \\ DICCA University of Genoa, Genoa, Italy. \\ ${ }^{2}$ Department of Earth and Environmental Sciences, University of Milano-Bicocca, Milan, \\ Italy.
}

Corresponding author: Marco Giovanni Malusà (marco.malusa@unimib.it)

\section{Key Points:}

- Catalog of relocated seismic events and focal mechanisms for the past 30 years

- Seismotectonic data interpretation in the light of geology and deep tectonic structures

- A revised seismotectonic model for the western Alpine region

\begin{abstract}
We analyze a fully reprocessed dataset of $\sim 9,000$ seismic events recorded in the western Alpine region during the past 30 years, in order to understand how convergence between Africa and Eurasia is presently accommodated at the transition between the opposite-dipping Alpine and Apenninic slabs. We confirm that seismicity in the Internal Zone of the Western Alps is clustered along two different arcs (Briançonnais and Piedmont arcs), clearly outlined by events in the $0-12 \mathrm{~km}$ depth range. The Piedmont Arc is best outlined by events in the 12$30 \mathrm{~km}$ depth range, forming a narrow belt that matches the shape and location of the Ivrea gravity anomaly. In the Internal Zone, $\sigma_{3}$ is oblique to the orogen trend. Although the mountain range is spreading gravitationally at a shallow level, spreading occurs intermittently with other earthquakes that are more directly related to plate interactions. Strike-slip solutions are predominant for events of magnitude $\mathrm{M}_{1}>4$, and reverse solutions are dominant along the Piedmont Arc for events of magnitude $\mathrm{M}_{1}<4$. Nodal planes have dominant NNW-SSE and ENE-WSW orientations that are common to major faults mapped in the study area. Integration with available tectonic and geodynamic constraints indicates that lithology distribution in the subduction wedge, orientation of major faults within and outside the subduction zone, and the exhumation of mantle rocks at shallow depth concurrently determine a complex seismotectonic scenario that may be expected in other subduction zones worldwide.

\section{Introduction}

The western Alpine region (Fig. 1a, d) is located at the transition between the opposite-dipping Alpine and Apenninic slabs [Piromallo \& Morelli, 2003; Sun et al., 2019; Zhao et al., 2016]. It shows relatively minor seismicity [Chiarabba et al., 2005; Giardini et al., 1999] due to slow convergence between tectonic plates [Serpelloni et al., 2016; Sánchez et al., 2018]. However, it is a key area to understand how deformation is partitioned at the transition between subduction zones with opposite polarities, as surface geology has been investigated for more than a century, seismicity has been continuously recorded since the 1960s [Amato et al., 1997, Eva et al., 2010], and the deep tectonic structure is increasingly well-known thanks to recent geophysical investigations [e.g., Kästle et al., 2018; Salimbeni et al., 2018; Solarino et al., 2018; Zhao et al., 2015; 2020]. Several kinematic models have been proposed to explain the post-metamorphic evolution of the Alpine region, either invoking
\end{abstract}


horizontal indentation [e.g., Laubscher, 1988; Schmid et al., 2017; Tapponnier, 1977], microplate rotation [e.g., Ménard, 1988; Vialon, 1990], or syn- to post-orogenic gravitational collapse [Eva et al., 1997; Eva \& Solarino, 1998; Sue et al., 1999, 2007]. Recent studies also highlight the impact of Apenninic subduction on the former Alpine subduction zone [Carminati and Doglioni, 2012; Malusà et al., 2015; 2016a,b; Molli \& Malavieille, 2011], from shallow crustal levels [Malusà \& Balestrieri, 2012] to the asthenospheric mantle [Malusà et al., 2018; Salimbeni et al., 2018], as well as the potential impact of glaciations and erosion [Champagnac et al., 2007; Nocquet et al., 2016; Sternai et al., 2019].

In this article, we analyze the seismicity of the western Alpine region in the light of available tectonic and geodynamic constraints, based on a fully reprocessed dataset of 9,000 seismic events recorded in the past 30 years. Our results improve the seismotectonic picture of the western Alpine area and provide pinpoints to understand how convergence between Africa and Eurasia is presently accommodated along the Adria-Europe plateboundary zone.

\section{Tectonic Setting}

\subsection{Geology of the Western Alpine Region}

The complex geologic configuration of the western Alpine region was largely shaped by Cretaceous-to-Present convergence between Africa and Eurasia [Dewey et al., 1989; Jolivet et al., 2003], which led to the subduction of the Alpine Tethys and adjoining European paleomargin beneath the Adriatic microplate [Handy et al., 2010; Malusà et al., 2015]. The composite Alpine subduction wedge is well exposed in the so-called Internal Zone of the Western Alps (Fig. 1b) [Beltrando et al., 2010; Guillot et al., 2004]. It includes, from east to west: (i) Austroalpine units accreted to the Adriatic upper plate in the Late Cretaceous (brown in Fig. 1); (ii) a belt of eclogitic units rapidly exhumed in the late Eocene (dark blue in Fig. 1); and (iii) lower-grade frontal units piled up during the Paleogene (light blue in Fig. 1) [Lardeaux et al., 2006; Schmid et al., 2004]. The Eocene eclogite belt [Malusà et al., 2011] extends from the Lepontine dome to the Sestri-Voltaggio Fault (SVF in Fig. 1c) and includes tectonic domes of eclogitized European continental crust (Monte Rosa, Gran Paradiso, DoraMaira) enveloped by eclogitic metaophiolites (e.g., Viso, Voltri) [Bigi et al., 1990]. The Paleogene frontal units form a double-vergence stack of blueschist-to-greenschist facies cover sequences and basement slivers, locally capped by subgreenschist facies ophiolites (e.g., Chenaillet) and turbidites (e.g., Helminthoid Flysch units). The Frontal Pennine Fault (FPF in Fig. 1c; Nicolas et al., 1990a) separates the frontal units of the Internal Zone from the pre-Alpine basement of the External Zone (e.g, Mont Blanc, Belledonne and Argentera External Massifs) and overlying Helvetic-Dauphinois cover sequences [Bellahsen et al., 2012; Dumont et al., 2011].

The remarkably arcuate shape of the Alpine belt developed during different stages of the Alpine evolution. The arc at the transition between the Central and the Western Alps is mainly an inheritance of continental breakup [Malusà et al., 2015; Vialon, 1990], as attested by the continuous trend of the Ivrea gravity anomaly (Fig. 1b) that marks a slice of Adriatic mantle exhumed to shallow depth during Tethyan rifting [Nicolas et al., 1990a; Scafidi et al., 2006; Zhao et al., 2015; Schmid et al., 2017]. In the southern Western Alps, part of the Ivrea gravity anomaly can be ascribed to mantle wedge rocks exhumed to shallow (10-12 km) depth beneath the Dora-Maira in the late Eocene, possibly due to localized plate divergence during northward Adria motion [Liao et al., 2018a; Solarino et al., 2018]. The arc at the transition between the Western and the Ligurian Alps is a much younger feature of the AdriaEurope plate boundary zone [Jolivet et al., 2003; Malusà et al., 2015], developed during Neogene rollback of the Apenninic slab, the consequent opening of the Ligurian-Provençal 
a

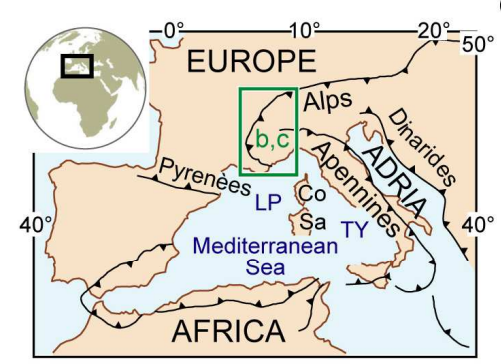

Co: Corsica LP: Ligurian-Provençal Basin Sa: Sardinia TY: Tyrrhenian Basin
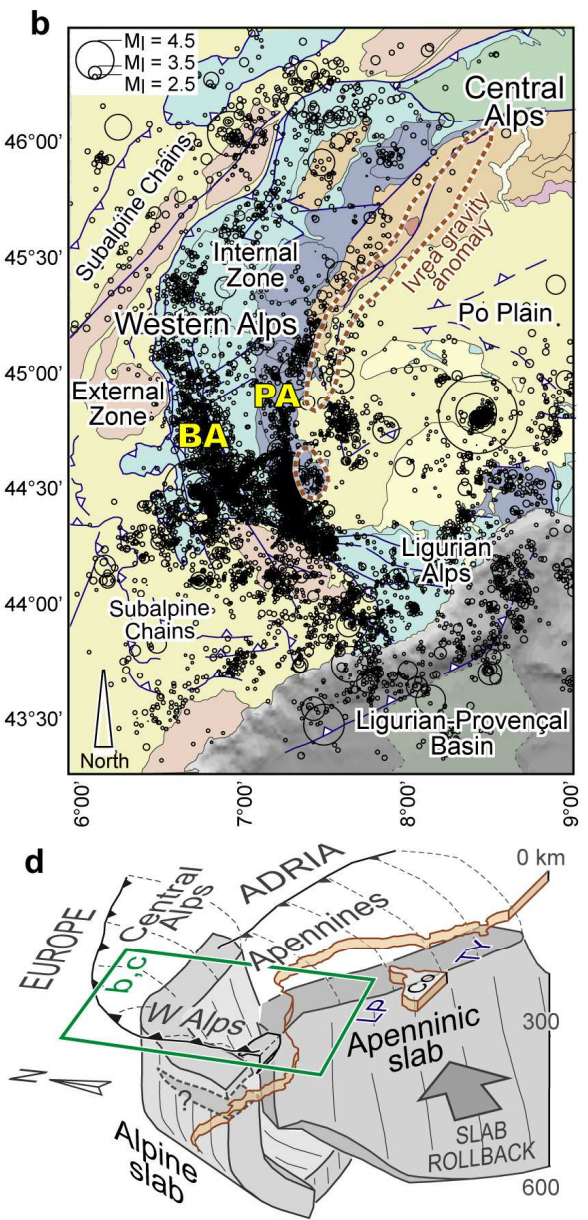

c

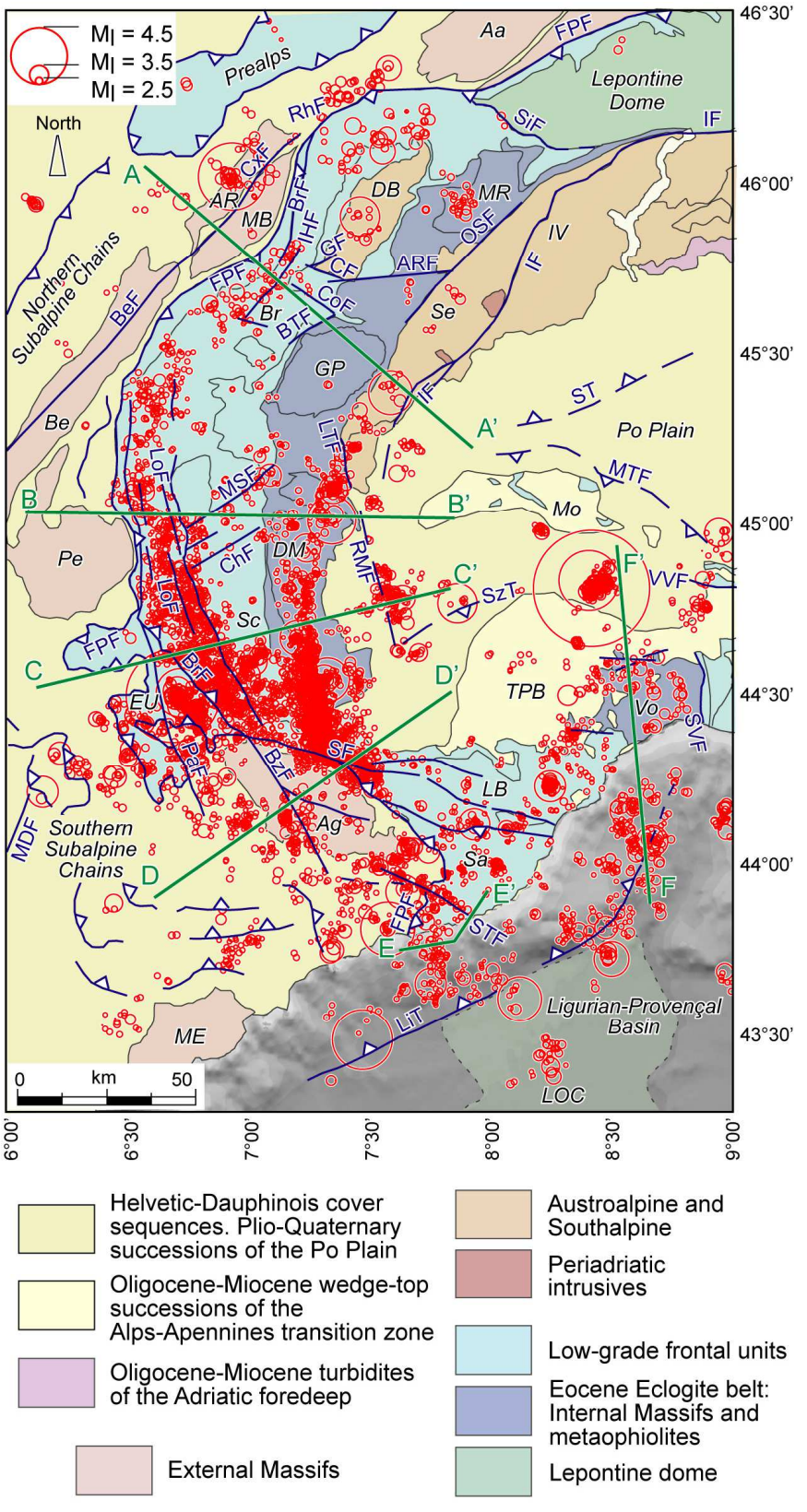

Figure 1. a: Tectonic sketch map of the Adria-Europe plate boundary zone and location of the western Alpine region (green box). b: Spatial distribution of seismic events with $\mathrm{M}_{1}>2.0$ recorded in the western Alpine region by the INGV National Central Seismic Network and surrounding local networks from 1986 to 2016 ( 9000 catalog events, black circles). These events define two long-recognized arcs, the Briançonnais Arc (BA) and the Piedmont Arc (PA). Ivrea gravity anomaly (0 mGal isoline, in brown) after Bigi et al. (1990). c: Same dataset after HypoDD relocation ( 7000 events, red circles). The green lines indicate the cross sections of Figs. 2 and 3a. Acronyms of tectonic domains (in black): Aa, Aar; Ag, Argentera; AR, Aiguilles Rouges; Be, Belledonne; Br, Briançonnais; DB, Dent Blanche; DM, Dora-Maira; EU, Embrunais-Ubaye; GP, Gran Paradiso; IV, IvreaVerbano; LB, Ligurian Briançonnais; LOC, Ligurian oceanic crust; MB, Mont Blanc; ME, Maures-Esterel; Mo, Monferrato; MR, M. Rosa; Pe, Pelvoux; Sa, Sanremo Flysch; Sc, Schistes lustrés; Se, Sesia-Lanzo; TPB, Tertiary Piedmont Basin; Vo, Voltri. Acronyms of major faults (in blue): ARF, Aosta-Ranzola Fault; BeF, Belledonne Fault; BrF, Briançonnais Fault; BTF, Belleface-Trajo Fault; BzF, Bersezio Fault; CF, Chaligne Fault; ChF, Chisone Fault; CoF, Cogne Fault; CxF, Chamonix Fault; FPF, Frontal Pennine Fault; GF, Gignod Fault; IF, Insubric Fault; IHF, Internal Houiller Fault; LiT, Ligurian Thrust; LoF, Longitudinal Faults; LTF, Lis- 
Trana Fault; MDF, Middle Durance Fault; MSF, Middle Susa Valley Fault; MTF, Monferrato Thrust Front; OSF, Ospizio Sottile Fault; PaF, Parpaillon Fault; RhF, Rhone Fault; RMF, Rivoli-Marene Deep Fault; SF, Stura Fault; SiF, Simplon Fault; ST, Southalpine Thrusts; STF, Saorge-Taggia Fault; SVF, Sestri-Voltaggio Fault; SzT, Saluzzo Thrust; VVF, Villalvernia-Varzi Fault. Tectonic map after Malusà et al. (2015). d: Slab structure beneath the western Alpine region (after Zhao et al., 2016). The question mark indicates the site of Alpine slab breakoff according to Kästle et al. (2020). Acronyms as in (a).

and Tyrrhenian basins in the Apenninic backarc [Faccenna et al., 2001], and the coeval counterclockwise rotation of the Corsica-Sardinia continental block [Gattacceca et al., 2007]. The southern part of the Alpine subduction wedge, which is unconformably overlain by the Oligocene-Miocene successions of the Tertiary Piedmont Basin (TPB in Fig. 1c), underwent major counterclockwise rotation at this stage [Collombet et al., 2002; Maffione et al., 2008], and was partly affected by Apenninic tectonics [e.g., Malusà \& Balestrieri, 2012; Mosca et al., 2010]. The Monferrato thrust front (MTF in Fig. 1c) bounds to the north this rotated segment of the Alpine subduction wedge. Farther north, the sedimentary succession of the Po Plain rests directly on top of the Mesozoic cover of the Adriatic microplate [Pieri \& Groppi, 1981].

The complex upper crustal structure of the western Alpine region mirrors the complexity documented by geophysical studies in the underlying upper mantle [e.g., Lippitsch et al., 2003; Piromallo \& Morelli, 2003; Giacomuzzi et al., 2011; Zhao et al., 2016, 2020; Hua et al., 2017; Kästle et al., 2018; Malusà et al., 2018; Solarino et al. 2018; Sun et $a l ., 2019]$. The western Alpine area is in fact located at the transition between the SE-dipping Alpine slab, to the north, and the SW-dipping Apenninic slab, to the south (Fig. 1d). Both slabs are imaged by recent high-resolution tomography models, but it is still debated whether the western Alpine slab experienced break-off [e.g., Lippitsch et al., 2003; Beller et al., 2018; Kästle et al., 2020] or not [e.g., Zhao et al., 2016; Hua et al., 2017; Ji et al., 2019].

\subsection{The Network of Major Faults}

The Cenozoic evolution of the western Alpine region has led to the development of a complex fault network in the upper crust (Fig. 1), investigated by several studies in the past twenty years [e.g., Bistacchi et al., 2000; Champagnac et al., 2004; Larroque et al., 2009; Malusà et al., 2006; 2009; Sanchez et al., 2010; Sue \& Tricart, 1999; 2003]. The major faults of the Internal Zone are generally parallel to the Frontal Pennine Fault and to the Alpine orogen trend (see Fig. 1c). They include the east-dipping Briançonnais Fault (BrF in Fig. 1c) [Bertrand et al., 1996; Bousquet et al., 2002] and the steeply dipping Internal Houiller Fault (IHF in Fig. 1c) [Malusà et al., 2005a,b; Polino et al., 2012] and Longitudinal Faults (LoF in Fig. 1c) [Barfety and Gidon, 1975; Sue et al., 2007]. Lower-rank faults lying at a higher angle to the orogen trend are found farther east, e.g., the Simplon Fault (SiF in Fig. 1c) at the boundary between the Western and the Central Alps [Campani et al., 2010; Mancktelow, 1985], the Aosta-Ranzola Fault (ARF in Fig. 1c) in the NW Alps [Bistacchi et al., 2001; Malusà et al., 2009] and the Middle Susa Valley Fault (MSF in Fig. 1c) in the SW Alps [Malusà, 2004; Perrone et al., 2011]. Other steeply dipping faults near-parallel to the orogen trend are found along the eastern boundary of the eclogitic tectonic domes, such as the Ospizio-Sottile (OSF in Fig. 1c) and Lis-Trana (LTF in Fig. 1c) faults [Bistacchi et al., 2000; Perrone et al., 2010]. Farther east, the dextral-reverse Insubric Fault (IF in Fig. 1c) juxtaposes Austroalpine units that have experienced Cretaceous metamorphism to Southalpine units bearing no evidence of Alpine metamorphic overprint [e.g., Schmid \& Kissling, 2000; Müller et al., 2001]. To the south, the Insubric and Lis-Trana faults merge beneath the western Po Plain into the Rivoli-Marene Deep Fault (RMF in Fig 1c) [Eva et al., 
2015], a steeply dipping tectonic structure rooted in the Adriatic lithospheric mantle [Malusà et al., 2017].

Major high-angle faults are also found in the External Zone of the Western Alps. They are the Chamonix (CxF in Fig. 1c) [Gurlay \& Ricou, 1983], Belledonne (BeF in Fig. 1c) [Thouvenot et al., 2003], Parpaillon (PaF in Fig. 1c) [Tricart, 2004] and Bersezio (BzF in Fig. 1c) [Sanchez et al., 2011] faults. Low-angle thrusts are found in a more external position beneath the External Massifs [Malusà et al., 2005a] and in the Subalpine Chains [Schwartz et al., 2017]. The Internal Zone of the Western Alps is bounded to the south by the steeply dipping Stura Fault (SF in Fig. 1c) [Ricou, 1981; Giglia et al., 1996], an ESE-WNW structure that displaced the Frontal Pennine Fault after deposition of the Annot Sandstone in the Oligocene [Malusà et al., 2009; 2015]). Other ESE-WNW faults are found all along the Ligurian coast in the Voltri, Ligurian Briançonnais and Sanremo Flysch units (e.g., the Saorge-Taggia Fault, STF in Fig. 1c) [Sanchez et al., 2010; Turino et al., 2009]. A major north-dipping thrust (Ligurian Thrust - LiT in Fig. 1c) is likely located offshore Liguria at the base of the continental slope [Larroque et al., 2001; 2011]. Major south-dipping thrusts are found beneath the western Po Plain (e.g, the Monferrato Thrust Front, MTF in Fig. 1c) [Pieri \& Groppi, 1981], in front of the north-dipping Southalpine thrusts (ST in Fig. 1c) [Fantoni et al., 2004].

\subsection{Seismicity in the Western Alpine Region}

Seismicity in the western Alpine region is mainly concentrated in the Internal Zone (Fig. 1b) and typically shows low to moderate magnitudes $\left(2<\mathrm{M}_{1}<4\right)$ [e.g., Béthoux et al., 1998; Eva \& Solarino, 1998; Eva et al., 1997; 1998; 2015; Godano et al., 2013; Jenatton et al., 2007; Sue et al., 1999]. Seismic events form two long-recognized arcs [Rothé, 1941], namely the Briançonnais Arc (BA in Fig. 1b) and the Piedmont Arc (PA in Fig. 1b) [Bethoux et al., 1998; Eva et al., 1997; Sue et al., 2007]. These seismic arcs apparently merge southward into a single belt (Fig. 1b), reaching as far south as the Ligurian coast where the seismicity is clustered offshore at the foot of the continental margin [Eva et al., 2001]. Outside either west or east of the Alpine Internal Zone, earthquake distribution is often clustered along major faults [e.g., Turino et al., 2009; Eva et al., 2015]. The Lepontine dome and the western Southern Alps are instead almost aseismic (Fig. 1b). Based on the analysis of focal mechanisms, several studies [e.g., Eva \& Solarino, 1998; Delacou et al., 2004; Sue et $a l ., 2007]$ have suggested a continuous area of extension in the core of the Western Alps, classically explained in terms of isostatic re-equilibration after cessation of Adria-Europe convergence. Other studies provide seismotectonic evidence of active convergence south of the Argentera [Larroque et al., 2009] and of active strike-slip faulting in the lithospheric mantle beneath the western Po Plain [Malusà et al., 2017].

\subsection{Geodetic Constraints}

Present-day convergence rates in the western Alpine area are generally $<1 \mathrm{~mm} / \mathrm{yr}$ [e.g., Calais et al., 2002; Nocquet \& Calais, 2003; Nocquet, 2012], i.e., much lower than those inferred by palinspastic reconstructions of the Alpine region for the Oligocene and the Miocene [e.g., Handy et al., 2010; Malusà et al., 2011, 2015] and much lower than geodetic uplift rates [Nocquet et al., 2016]. On the scale of the Central Mediterranean, geodetic studies document ongoing NW-ward convergence of Africa towards Eurasia at rates of 4-5 mm/yr [McClusky et al., 2003; Nocquet et al., 2006]. Most of this convergence is accommodated along the Maghrebides [Nocquet \& Calais, 2004; Serpelloni et al., 2007], but 10\% of that motion is likely transferred northward to Sardinia and Corsica [Larroque et al., 2009; Nocquet, 2012]. Continuous GPS measurements indicate convergence at rates of 0.4-0.8 $\mathrm{mm} / \mathrm{yr}$ between Corsica, to the south, and the Ligurian Alps, the Monferrato and the 
Provençal coast to the north [see Larroque et al., 2009, their Fig. 4]. North of the LigurianProvençal basin, GPS measurements indicate convergence between the Provençal coast and the Monferrato (at rates of 0.2-0.4 mm/yr), extension between the Argentera Massif and the Monferrato (at rates of 0.2-0.7 mm/yr), and convergence between the Provençal coast and the Argentera Massif (at rates of 0.3-0.9 mm/yr) [Larroque et al., 2009]. Recent geodetic measurements confirm extension at higher rates in the southern Internal Zone compared to the Argentera Massif, and shortening in the foreland areas [Walpersdorf et al., 2018]. GPS data are also consistent with a counterclockwise rotation of Adria relative to Eurasia around a pole located in the western Po Plain [Calais et al., 2002], but the number, shape and size of different fault blocks possibly involved in such rotation are still poorly understood. Rightlateral slip associated with Adria rotation $(\sim 0.5 \mathrm{~mm} / \mathrm{yr})$ would be distributed over a 130-kmwide belt in the northern Western Alps, and may decrease southwards [Walpersdorf et al., 2018].

\section{Methods}

For this study, we selected seismic events recorded by the INGV National Central Seismic Network (2006) from 1986 to 2016 within an area spanning from $43^{\circ} 15^{\prime}$ to $46^{\circ} 30^{\prime}$ in latitude and from $6^{\circ} 00^{\prime}$ to $9^{\circ} 00^{\prime}$ in longitude, with magnitude $\mathrm{M}_{1}>2.0$ to ensure the completeness of the catalog [e.g., Amato \& Mele, 2008]. The initial dataset includes 9,190 catalog events that are reported in the map of Fig. 1b. Standard procedures of earthquake location (e.g., using Hypoellipse [Lahr, 1999]) are not able to account for the lateral variations in mean crustal and upper mantle velocities (and Moho depth) expected in the study area due to its complex tectonic setting [e.g., Buness et al., 1990; Kissling \& Spakman, 1996; Scafidi et al., 2009; Solarino et al., 2018]. In order to improve the relative precision of earthquake positions, we have reprocessed the whole earthquake dataset using HypoDD [Waldhauser \& Ellsworth, 2000]. The HypoDD code is weakly dependent from the initial velocity model when the distance between events is small compared to the event-station distance and the scale-length of velocity heterogeneity [Waldhauser, 2001]. However, in a large area, this is not always fulfilled; we then employed a reliable min1D model [Kissling, 1988; Scafidi et al., 2006] to avoid biased relocations in the presence of velocity model errors [Michelini \& Lomax, 2004]. Residuals between observed and theoretical travel-time differences are minimized by the algorithm for pairs of earthquakes at each station. When using double-difference algorithms, reliable starting locations are important to ensure that the theoretical ray paths are calculated correctly [Michelini \& Lomax, 2004]. Nowadays, strict cooperation among seismic networks makes comprehensive waveform datasets available to the scientific community. However, processing of these data is not performed routinely except for few stations at the borders between countries. We then complemented the original catalog, especially for the oldest events, by phase picking from surrounding and temporary networks [RESIF, 1995; Sismalp; SSS Swiss Seismological Service (SED) at ETH Zurich, 1983; RSNI - University of Genoa, 1967] to guarantee a more complete dataset. To avoid unstable solutions, events utilized for pairing should be well linked, which implies a selection of input data to ensure the accuracy in the location procedure. As a result, the number of relocated earthquakes typically decreases compared to the original dataset. The clustering parameters used during the several runs of HypoDD were intended to create tight clusters without excluding many events from the final dataset (see Supplementary material for details). HypoDD can compute the result using two algorithms: SVD (Singular Value Decomposition) and LSQR (Conjugate Gradient Least Squares). SVD is computationally demanding and is used for small datasets, whereas LSQR is applicable to larger datasets. Our final dataset includes 7212 earthquakes that were relocated using the LSQR algorithm. However, the location errors provided by LSQR are generally underestimated [Waldhauser \& Ellsworth, 2000] and should be assessed independently. We 
then selected $~ 1600$ earthquakes for relocation using both LSQR and SVD (see supplementary material for details) and compared the obtained locations and errors to get an estimate of LSQR performance compared to SVD [Douilly et al., 2013]. Our reliability analysis shows that the depth location errors computed with SVD are lower than $2 \mathrm{~km}$ for $86 \%$ of the relocated events, and the horizontal location errors are lower than $2 \mathrm{~km}$ for $80 \%$ of the relocated events. The highest errors, up to $20 \mathrm{~km}$, are found in the southernmost part of the study area due to the poorer azimuthal coverage of seismic stations.

We computed 106 fault plane solutions using the first onset technique [Reasenberg \& Oppenheimer, 1985] for earthquakes with $\mathrm{M}_{1}>2.5$ having at least 15 readable and well distributed polarities around the hypocenter (see supplementary Table S1). We did not use lower magnitude events in our analysis as they were recorded by fewer seismic stations, especially in the past decades when instrument sensitivity was low. Moreover, the Po Plain is a noisy area for seismic signals and, even when recorded, lower magnitude events often have a poor signal-to-noise ratio that makes the recognition of the first onset questionable. Only in the recent past the improved distribution of seismic stations, both in terms of number of instruments and azimuthal coverage, has made the computation of low magnitude - high quality focal solutions possible [e.g., Beaucé et al., 2019]. Our dataset was eventually complemented with focal mechanisms from previous studies either obtained by the same technique [Baroux et al., 2001; Eva \& Solarino, 1998; Eva et al., 1998; Eva et al., 2015; Massa et al., 2006; Nicolas et al., 1990b; Nicolas et al., 1999; Perrone et al., 2010; Sue et al., 1999; Turino et al., 2009] or by waveform inversion [Pondrelli et al., 2006; Scognamiglio et al., 2009].

The resulting dataset of relocated events and fault-plane solutions was analyzed for different depth ranges and subareas within the framework of the geological and geophysical constraints available for the western Alpine area. In order to evaluate the impact of the exhumed mantle wedge, imaged at depths as shallow as 10-12 km beneath the Dora-Maira by recent tomography models [Solarino et al., 2018; Zhao et al., 2020], we have considered events in the $0-12 \mathrm{~km}$ and $12-30 \mathrm{~km}$ depth ranges separately. We have also plotted separately the fault plane solutions for events of magnitude $\mathrm{M}_{1}<4.0$ and $\mathrm{M}_{1}>4.0$, as the latter are potentially more representative of the reactivation of major faults described in Sect. 2.2. In each subarea, we have also applied a stress tensor inversion method [Gephart \& Forsyth, 1984] to the focal mechanism solutions.

\section{Results}

\subsection{Relocated Seismic Events in Map View and Cross Section}

The resulting dataset of $\sim 7200$ earthquakes relocated with HypoDD is reported in Fig. 1c (map view) and Fig. 2 (cross sections). In Fig. 2, the earthquake distribution after HypoDD relocation (in red) is compared with the initial distribution obtained with Hypoellipse (in grey). Some examples of improved clustering of seismic events after HypoDD relocation are also shown (insets to the right in Fig. 2). Note that many of the earthquakes were mislocated in the initial catalog and were moved to the new HypoDD location, but 1800 events were not located ("lost") because of missing links to other clusters. However, Fig. 2 shows that the consequent loss of information can be considered negligible for the aims of our study.

The map of relocated seismic events (Fig. 1c) confirms the clustering of seismicity in the Internal Zone along two different arcs [Rothé, 1941]. The Briançonnais and Piedmont arcs are clearly separated in Fig. 1c. The Briançonnais Arc runs parallel to the orogen trend and to the major longitudinal faults of the Internal Zone (PFT, BrF, IHF and LoF in Fig. 1c). It can be continuously followed as far north as the Gran Paradiso dome (GP in Fig. 1c), and 
more discontinuously as far north as the Dent Blanche (DB in Fig. 1c). The Piedmont arc runs obliquely to the Eocene Eclogite belt. It cuts across the Dora-Maira dome (DM in Fig. 1c) from SSW to NNE, and it can be continuously followed as far north as the southern tip of the Sesia-Lanzo unit (Se in Fig. 1c). Farther north, the seismicity along the potential northward prolongation of the Piedmont Arc is more scattered. Both the Briançonnais and the Piedmont arcs terminate to the south against the Stura Fault (SF in Fig. 1c). Therefore, these arcs do not merge southwards. In the Internal Zone, the seismicity gap between the two arcs is locally bridged by earthquakes aligned along lower-rank faults oblique to the orogen trend (e.g., MSF and ChF in Fig. 1c). After relocation, no seismicity cluster was obtained along well-known tectonic structures such as the Aosta-Ranzola, Insubric and Sestri-Voltaggio faults (ARF, IF and SVF in Fig. 1c), whereas clusters are found in correspondence to the Monte Rosa (MR in Fig. 1c) and the Dent Blanche. In general terms, the Internal Zone of the Western Alps shows a higher frequency of $\mathrm{M}_{1}>2.0$ events in the southern part than in the northern part. The highest frequency of seismic events is observed immediately to the north of the Stura Fault (Fig. 1c).

Earthquakes in the External Zone are generally more scattered. Seismicity clusters are found to the southwest of the Aar Massif (Aa in Fig. 1c), in the Aiguilles Rouges - Mont Blanc massifs (AR and MB in Fig. 1c), in the Argentera Massif (Ag in Fig. 1c) and in the Southern Subalpine Chains. Only few events have been successfully relocated around the Belledonne Massif, but far away from the Belledonne Fault that has been recently described as seismically active [Thouvenot et al., 2003], whereas an evident ESE-WNW alignment of seismic events is observed along the Saorge-Taggia Fault (STF in Fig. 1c).

In the western Po Plain, a clear NNW-SSE alignment of seismic events marks the Rivoli-Marene Deep Fault (RMF in Fig. 1c), and clusters of seismic events are found along the westward continuation of the Villalvernia-Varzi Fault (VVF in Fig. 1c). Seismicity offshore Liguria is clustered along the Ligurian Thrust (LiT in Fig. 1c), but earthquakes are also recorded in the deepest parts of the Ligurian-Provençal basin (LOC in Fig. 1c).

Figure 2 shows earthquake distribution along six cross sections perpendicular to the orogen trend. Such distributions are compared in Fig. 3a with surface geology and deep crustal structure as constrained by geophysical data [Eva et al., 2015, 2016; Malusà et al., 2015; Roure et al., 1990; Solarino et al., 2018; Zhao et al., 2015]. Cross section A-A' runs from the Aiguilles Rouges - Mont Blanc massifs through the Gran Paradiso dome to the Po Plain (Fig. $3 a)$. Along this transect, seismicity is mainly concentrated in the $0-10 \mathrm{~km}$ depth range, between the Frontal Pennine Fault and the Internal Houiller Fault (FPF and IHF in Figs. 2 and 3a). Only few events are recorded in the Briançonnais units farther east ( $\mathrm{Br}$ in Fig. 3a). The Gran Paradiso dome (GP in Fig. 3a) is almost aseismic, whereas scattered seismic events are recorded down to $\sim 15 \mathrm{~km}$ depth in the Sesia-Lanzo unit (Se in Fig. 3a), and in the $20-40 \mathrm{~km}$ depth range beneath the western Po Plain. In the External Zone, seismicity is concentrated in the 0-10 km depth range along thrust faults beneath the External Massifs (Fig. 3a).

Cross section B-B' runs from the Pelvoux Massif (Pe in Fig. 3a) through the northern part of the Dora-Maira dome (DM in Fig. 3a) to the western tip of the Monferrato hills (Mo in Fig. 3a). Along this transect, scattered seismicity is recorded in the External Zone, down to $15 \mathrm{~km}$ depth (Fig. 3a). Seismic events in the Internal Zone are evenly distributed in the 0-10 $\mathrm{km}$ depth range across the whole stack of low-grade frontal units, although events are more frequent between the Frontal Pennine Fault and the Longitudinal Faults (FPF and LoF in Fig. 2). In the Dora-Maira dome, seismicity is recorded down to $20 \mathrm{~km}$ depth (Fig. 3a), whereas seismicity beneath the Po Plain is clustered at 25-30 km depth (Fig. 2). 
Figure 2
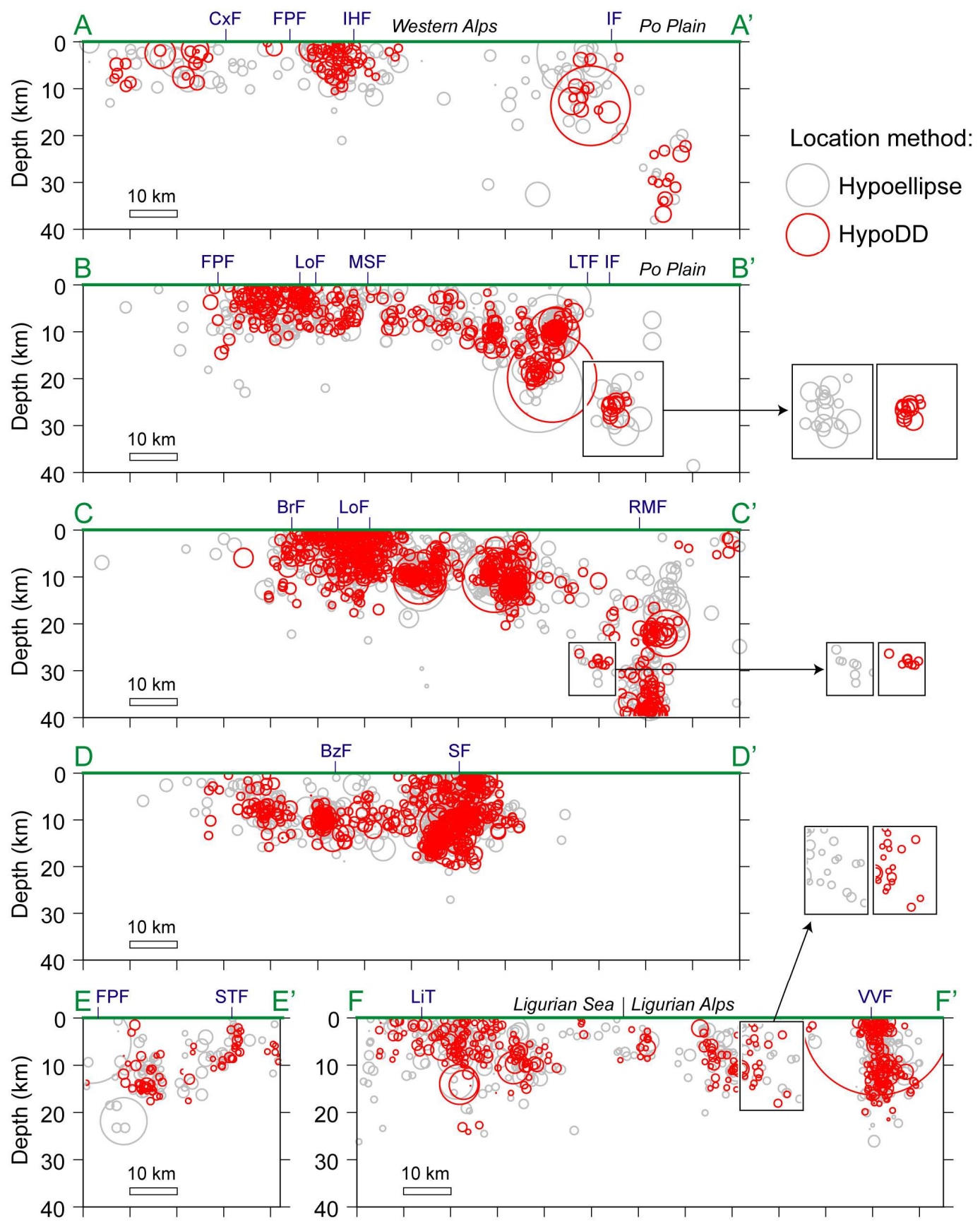

Figure 2. Earthquake distribution before (in grey) and after HypoDD relocation (in red) along six representative cross sections perpendicular to the orogen trend (see locations in Fig. 1c). Events are projected from a $20 \mathrm{~km}$ thick swath profile (keys and acronyms as in Fig. 1). The insets to the right highlight the improved clustering of seismic events after HypoDD relocation. 
Cross section C-C' runs from the Embrunais-Ubaye nappe (EU in Fig. 3a) through the southern part of the Dora-Maira dome (DM in Fig. 3a) to the western Po Plain. Along this transect, seismicity in the External Zone is concentrated in the vicinity of the Frontal Pennine Fault down to 15-20 km depth (Fig. 3a), but most seismic events are recorded in the frontal units of the Internal Zone, in the $0-12 \mathrm{~km}$ depth range along the Briançonnais and Longitudinal faults (BrF and LoF in Figs. 2 and 3a), and farther east within the Schistes lustrés (Sc in Fig. 3a). Diffuse seismicity down to $15-20 \mathrm{~km}$ depth is documented in the western part of the Dora-Maira dome, whereas scattered events in the $\sim 10-15 \mathrm{~km}$ depth range are documented in the eastern part of the dome, on top of the underlying mantle-wedge rocks (Fig. 3a). Seismicity beneath the western Po Plain is found at depths $>20 \mathrm{~km}$ in correspondence with the Rivoli-Marene Deep Fault (RMF in Fig. 2).

Cross section D-D' runs from the Southern Subalpine Chains through the Argentera Massif (Ag in Fig. 3a) to the Tertiary Piedmont Basin (TPB in Fig. 3a). Along this transect, the Argentera basement is juxtaposed at the surface against Ligurian Briançonnais units (LB in Fig. 3a) by the steeply dipping Stura Fault (SF in Figs. 2 and 3a). This fault is marked by a dense alignment of seismic events continuously recorded from 0 to $20 \mathrm{~km}$ depth. The events to the NE of the Stura Fault may mark the Frontal Pennine Fault beneath the Ligurian Briançonnais units (Fig. 3a). To the SW, seismic events in the $0-15 \mathrm{~km}$ depth range mark the external thrusts beneath the Argentera Massif [Eva et al., 2016].

Cross section E-E' cuts the Frontal Pennine Fault (FPF in Fig. 2) along the Ligurian coast. There, earthquakes in the European continental crust are clustered in the uppermost 20 $\mathrm{km}$. In the Sanremo Flysch unit (Sa in Fig. 2), a continuous vertical alignment of seismic events marks the Saorge-Taggia Fault (STF in Fig. 2), which can be followed down to $12 \mathrm{~km}$ depth within the European basement (Fig. 3a).

Cross section F-F' runs from the base of the Ligurian-Provençal continental slope through the Voltri metaophiolites (Vo in Fig. 3a) to the eastern tip of the Monferrato hills (Mo in Fig. 3a). Offshore, earthquakes are mainly clustered in the $0-15 \mathrm{~km}$ depth range along the Ligurian Thrust (LiT in Figs. 2 and 3a). Onshore, relocated seismic events define vertical alignments down to $15-20 \mathrm{~km}$ depth, in correspondence to major structures such as the Villalvernia-Varzi Fault (VVF in Fig. 2).

\subsection{Distribution of Relocated Seismic Events with Depth}

The distribution of relocated seismic events is analyzed in Fig. 3b-d for different depth ranges $(0<Z<12 \mathrm{~km}, 12<Z<30 \mathrm{~km}$ and $Z>30 \mathrm{~km})$ identified according to the deep structure revealed by recent geophysical investigations. Seismic events deeper than $30 \mathrm{~km}$ are expected to provide clues on the seismicity in the Adriatic upper mantle, whereas events in the $30-12 \mathrm{~km}$ and $12-0 \mathrm{~km}$ depth ranges are analyzed separately to highlight the potential role of the exhumed mantle wedge beneath the Dora-Maira, as its top is located around 10-12 km depth according to recent local earthquake tomography models [Solarino et al., 2018].

Both the Briançonnais and Piedmont arcs are clearly outlined even by considering only seismic events in the $0-12 \mathrm{~km}$ depth range. The map of Fig. $3 \mathrm{~b}$ does include most of the features observed in the map of Fig. 1c, apart from the seismicity immediately to the east of the Ivrea gravity anomaly and the seismicity in the deepest part of the Ligurian-Provençal Basin. By considering only earthquakes in the 12-30 km depth range (Fig. 3c), the Briançonnais Arc disappears. Few scattered earthquakes apparently lying within the frontal units of the Alpine subduction wedge are instead located in the footwall of the Frontal Pennine Fault, well within the European basement (see cross section C-C' in Fig. 3a). Some 

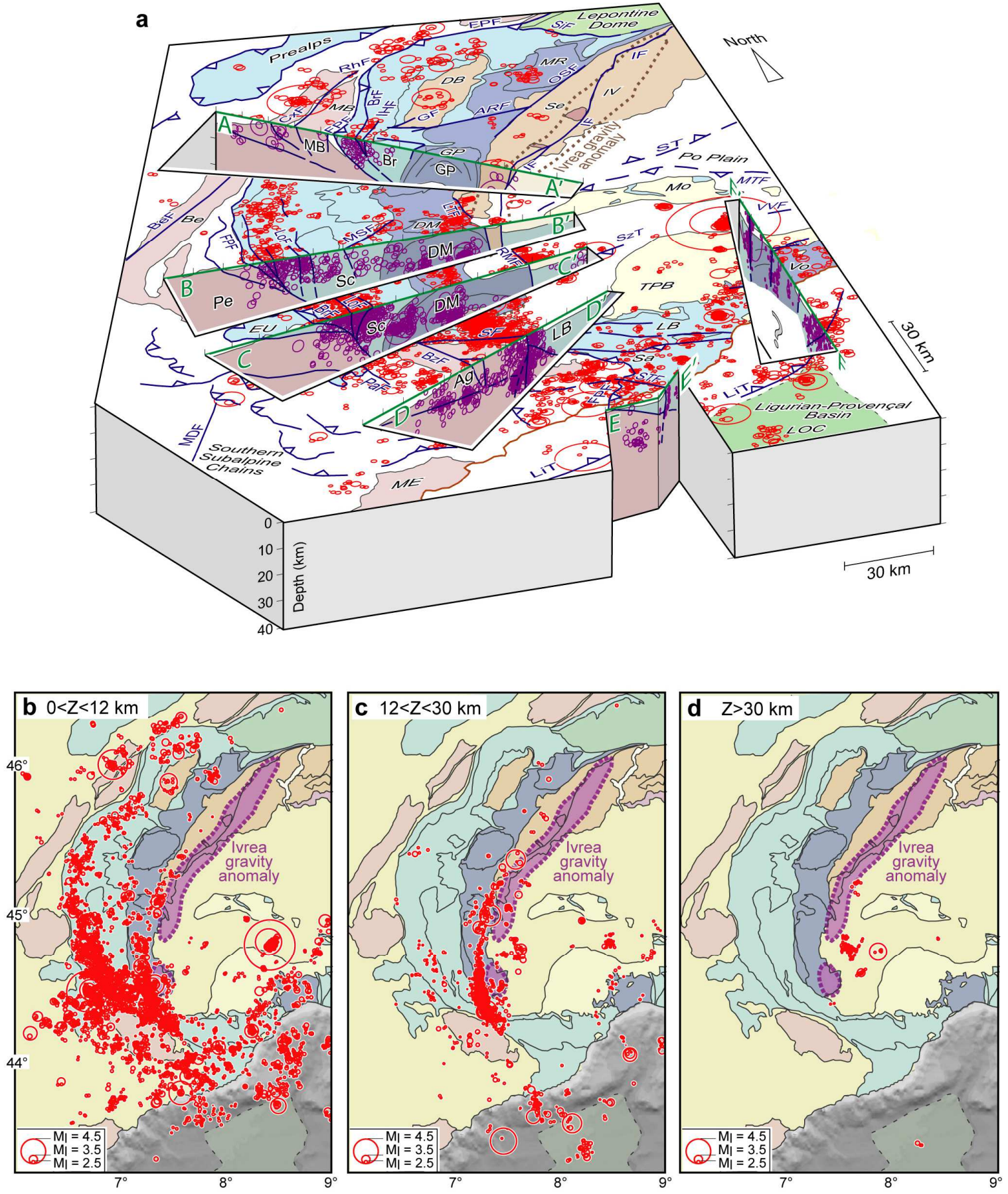

Figure 3. a: Three-dimensional model of the western Alpine region portraying the spatial relationships between major faults (blue lines) and HypoDD-relocated seismic events, indicated by red circles in map view and by purple circles in cross-section (same as in Fig. 2). Tectonic sketch map after Bigi et al., 1990 and Malusà et al. (2015); cross-sections based on Eva et al. (2015), Malusà et al. (2015), Roure et al. (1990), Solarino et al. (2018) and Zhao et al. (2015). Keys and acronyms as in Fig. 1. b-d: Map distribution of HypoDD-relocated seismic events for different depth ranges $(b=0<Z<12 \mathrm{~km} ; \mathrm{c}=12<\mathrm{Z}<30 \mathrm{~km} ; \mathrm{d}=\mathrm{Z}>30 \mathrm{~km})$, and relationships with the Ivrea gravity anomaly (purple dashed line $=0 \mathrm{mGal}$ isoline, after Bigi et al., 1990). Seismic events in the $12<\mathrm{Z}<30 \mathrm{~km}$ depth range (frame c) define an arcuate belt that matches the shape and location of the Ivrea gravity anomaly. 
of them originate in the European lower crust [Malusà et al., 2017, their Fig. 2]. The Piedmont Arc is outlined even better in Fig. 3c than in Fig. 3b. Earthquakes in the 12-30 km depth range define a narrow and continuous arcuate belt from the Stura Fault to the Lis-Trana Fault, which matches the shape and location of the southern part of the Ivrea gravity anomaly (in purple in Fig. 3c). Scattered events are observed beneath the Sesia-Lanzo, whereas a NNW-SSE alignment of events is observed along the southward prolongation of the LisTrana fault, marking the Rivoli-Marene Deep Fault (Fig. 3c). Seismic events arranged according to NNW-SSE linear trends are also observed, in Fig. 3c, along the continental margin offshore Liguria, where these alignments match with faults mapped by Chaumillon et al. [1994]. Earthquakes deeper than $30 \mathrm{~km}$ are exclusively found to the east of the Ivrea gravity anomaly (Fig. 3d). Most of them are aligned along the Rivoli-Marene Deep Fault.

\subsection{Distribution of Focal Mechanisms}

Figure 4 shows the spatial distribution of focal mechanisms for seismic events of magnitude $2.5<\mathrm{M}_{1}<4$ and for the same depth ranges considered in Sect. 4.2 and Fig. 3b-d. Beach balls are color-coded according to focal mechanism categories (normal, obliquenormal, strike-slip, oblique-reverse and reverse) as defined by Cronin [2010]. Background circles in pale green are the relocated events of Fig. 3b-d.

Based on the tectonic setting described in Sect. 2.2, we have subdivided the study area into seven different subareas that will be discussed separately. The External and Internal zones of the NW and SW Alps have been considered as distinct subareas because of the different boundary conditions characterizing the eastern side of the Western Alps to the north and to the south of the Monferrato Thrust Front. In fact, the Internal Zone to the north of the Monferrato Thrust Front (subarea 2 in Fig. 4) is bounded to the east by a continuous slice of Adriatic mantle exhumed to shallow depth during Tethyan rifting [Nicolas et al., 1990a; Malusà et al., 2015]. Instead, the Internal Zone to the south of the Monferrato Thrust Front (subarea 4 in Fig. 4 ) is bounded to the east by metamorphic units that were originally part of the Alpine subduction wedge, but have experienced major post-metamorphic rotations and are now buried beneath the Cenozoic sediments of the Tertiary Piedmont Basin (axial belt domain 2 in Eva et al., 2015). Subarea 4 shows a much higher frequency of seismic events compared to subarea 2 , and it is also the site where the Briançonnais and Piedmont arcs are more evident. Focal mechanisms in the western Po Plain, the Ligurian Alps and the Ligurian Sea (subareas 5 to 7 in Fig. 4) are also discussed separately in the light of the different underlying geology.

In the northern External Zone (subarea 1), focal mechanisms are dominantly obliquenormal in the Aiguilles Rouges and Mont Blanc massifs, and exclusively strike-slip north of the Rhone Valley, where the observed ENE-WSW alignment of seismic events is consistent with computed nodal planes (Fig. 4a).

In the northern Internal Zone (subarea 2), normal focal mechanisms are mainly distributed along a $\sim 10-15 \mathrm{~km}$ wide belt parallel to the Simplon Fault, in its hanging wall (Fig. 4a). Farther south in subarea 2, focal mechanisms are dominantly strike-slip, even though normal to oblique-normal focal solutions are also present. For example, a normal focal solution was computed in the Upper Aosta Valley in correspondence with a major fault bend. 
Figure 4
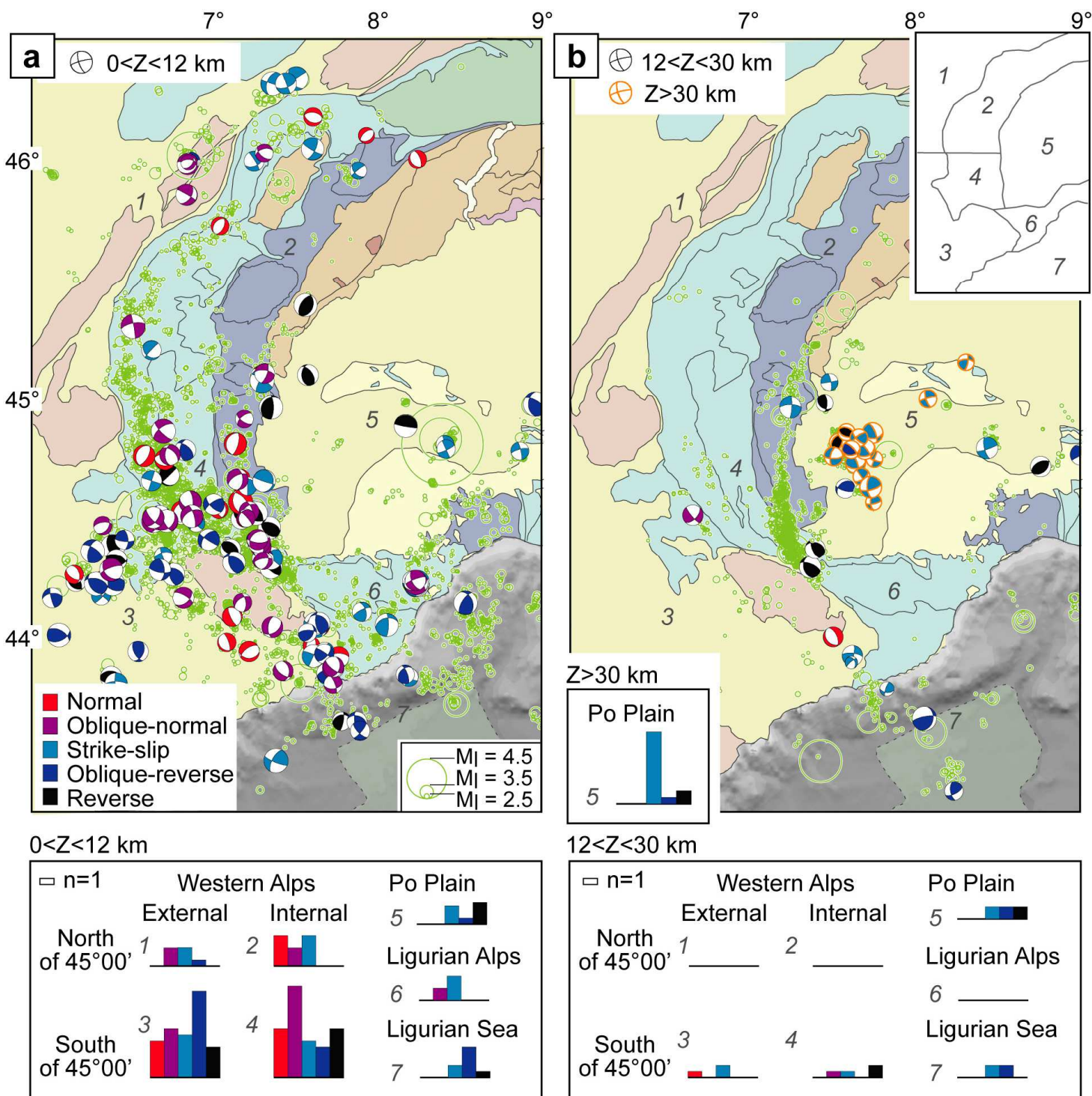

Figure 4. Spatial distribution of focal mechanisms for events of magnitude $2.5<\mathrm{M}_{1}<4$ and for different depth ranges $(\mathrm{a}=0<\mathrm{Z}<12 \mathrm{~km} ; \mathrm{b}=12<\mathrm{Z}<30 \mathrm{~km}$ and $\mathrm{Z}>30 \mathrm{~km})$, based on own computations and literature data from Baroux et al. (2001), Eva and Solarino (1998), Eva et al., (1998); Eva et al. (2015), Massa et al., 2006: Nicolas et al. (1990b), Nicolas et al. (1999), Perrone et al., (2010), Pondrelli et al. (2006), Sue et al. (1999),

Scognamiglio et al. (2009), Turino et al. (2009). Circles in pale green are the relocated seismic events of Fig. $3 \mathrm{~b}$-d. Histograms in the lower row show the frequency distribution of different mechanisms in subareas 1 to 7 (see subareas boundaries in the inset on the top-right). Color codes are referred to focal mechanism categories according to Cronin (2010) (normal: rake $-110^{\circ}$ to $-70^{\circ}$; oblique-normal: $-160^{\circ}$ to $-110^{\circ},-70^{\circ}$ to $-20^{\circ}$; strikeslip: $-20^{\circ}$ to $20^{\circ},-180^{\circ}$ to $-160^{\circ}, 160^{\circ}$ to $180^{\circ}$; oblique-reverse: $20^{\circ}$ to $70^{\circ}, 110^{\circ}$ to $160^{\circ}$; reverse: $70^{\circ}$ to $110^{\circ}$ ).

In the southern External Zone (subarea 3), focal mechanisms are dominantly obliquereverse, but all the other categories of mechanisms are also present, and almost equally represented (see histograms in Fig. 4). Normal mechanisms are concentrated along a WNWESE belt to the south of the Argentera Massif (Fig. 4a), but they are progressively replaced to the north by oblique-normal mechanisms, and farther north by oblique-reverse mechanisms. To the southwest, oblique-reverse to reverse mechanisms are dominant in the southern Subalpine Chains. 
In the southern Internal Zone (subarea 4), focal mechanisms in the 0-12 km depth range are dominantly oblique-normal, both along the Briançonnais and Piedmont arcs, but all the other categories of mechanisms are also present and almost equally represented (see histogram in Fig. 4a). Reverse, oblique-reverse, strike-slip and oblique-normal mechanisms are evenly distributed in the whole subarea 4 from the Stura Fault to the northern Dora-Maira, whereas normal mechanisms are exclusively found between latitude $44^{\circ} 30^{\prime} \mathrm{N}$ and latitude $44^{\circ} 50^{\prime} \mathrm{N}$ (Fig. 4a). In the 12-30 km depth range reverse solutions are dominant beside minor strike-slip and oblique-normal solutions (Fig. 4b).

Beneath the western Po Plain (subarea 5), strike-slip, oblique-reverse and reverse solutions are almost equally represented, both in the $0-12 \mathrm{~km}$ and in the $12-30 \mathrm{~km}$ depth range. Strike-slip mechanisms are dominant at depths $>30 \mathrm{~km}$ (beach balls outlined in orange in Fig. 4b), where they are associated to events clustered along the Rivoli-Marene Deep Fault.

In the Ligurian Alps (subarea 6), strike-slip events are dominant and evenly distributed in the whole subarea, but oblique-normal solutions are also present near Finale Ligure [Cattaneo et al., 1997]. In the Ligurian Sea (subarea 7), earthquakes in the 0-12 km depth range are strike-slip to reverse with a majority of oblique-reverse solutions (Fig. 4a), whereas strikeslip and oblique-reverse solutions are found in the $12-30 \mathrm{~km}$ depth range (Fig. $4 \mathrm{~b}$ ).

Figure 5

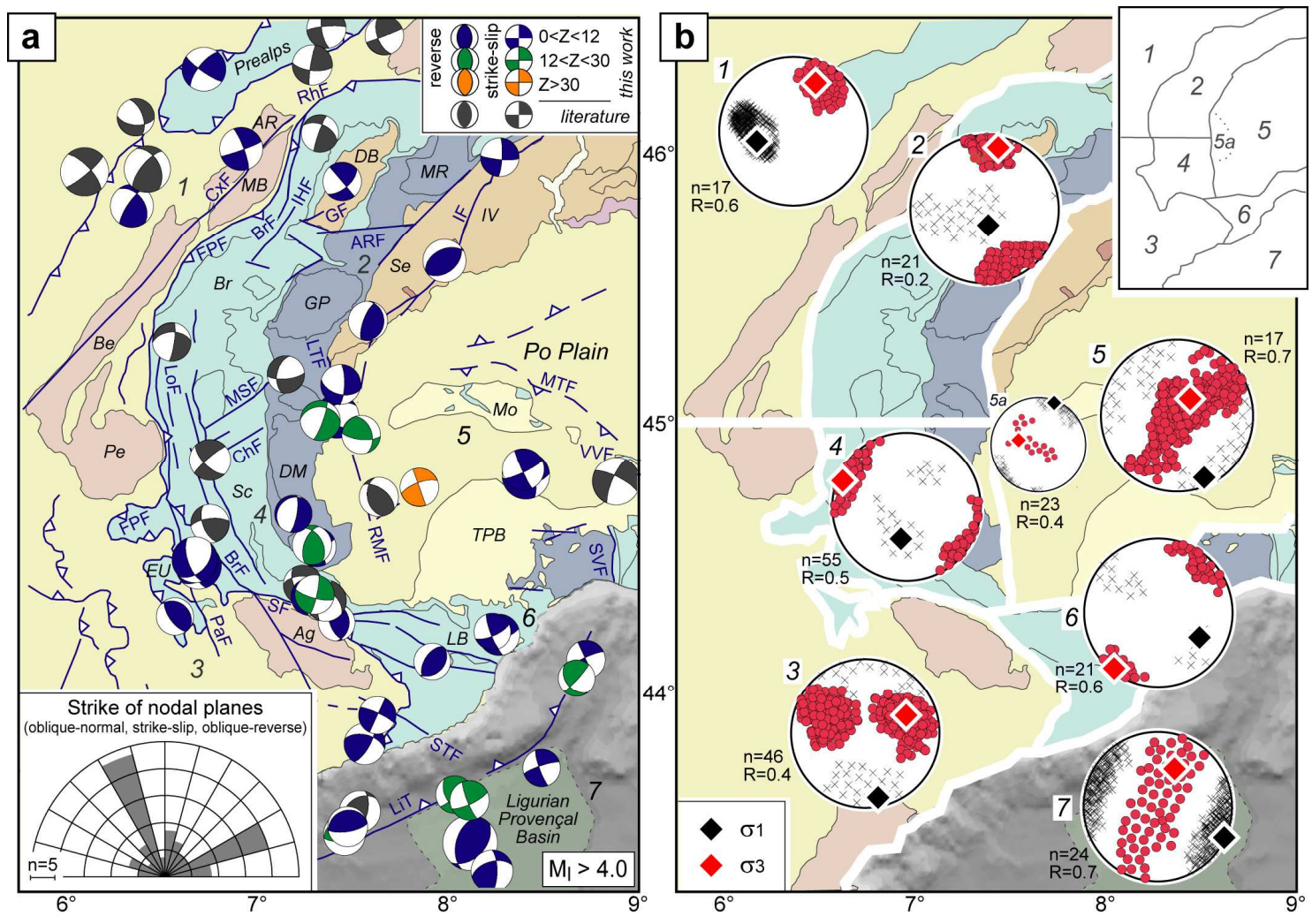

Figure 5. a: Focal mechanisms for seismic events with magnitude $M_{1}>4.0$, based on own computed data (color-coded according to depth range) and literature data (in grey, Baroux et al. 2001, Eva \& Solarino 1998, Eva et al. 1998, Eva et al. 2015, Massa et al. 2006, Nicolas et al. 1990b, Nicolas et al. 1999, Perrone et al. 2010, Pondrelli et al. 2006, Scognamiglio et al. 2009, Sue et al. 1999, Turino et al. 2009). The rose diagram on the bottom-left shows the strike of nodal planes for oblique-normal, strike-slip and oblique-reverse events.

Acronyms as in Fig. 1. b: Results of stress tensor inversion (Gephart \& Forsyth, 1984) for subareas 1 to 7 based on focal solutions for events of magnitude $M_{1}>2.5$. Lozenges $=\sigma_{1}$ and $\sigma_{3}$ main stress axes; black crosses and red dots $=90 \%$ confidence limits; $\mathrm{R}=\left(\sigma_{2}-\sigma_{1}\right) /\left(\sigma_{3}-\sigma_{1}\right) ; \mathrm{n}=$ number of events. 
Figure 5a shows the spatial distribution of focal mechanisms for seismic events of magnitude $\mathrm{M}_{1}>4$, color-coded according to event depth. Beach balls in grey are referred to literature data [Eva \& Solarino, 1998; Eva et al., 2015; Nicolas et al., 1990b; Pondrelli et al., 2006; Scognamiglio et al., 2009; Sue et al., 1999; Thouvenot et al., 2003]. When this map is compared to the maps of Fig. 4, it is evident that strike-slip mechanisms become dominant for events of magnitude $M_{1}>4$ : they are found in all the subareas 1 to 7 . Reverse mechanisms are also common: they are found in subareas 2, 3,6 and 7. The strike of nodal planes for oblique-normal, strike-slip and oblique-reverse events of magnitude $\mathrm{M}_{1}>4$ are summarized in the inset of Fig. 5a. Nodal planes are dominantly NNW-SSE and ENE-WSW, and these orientations are remarkably constant in all of the different subareas.

The results of stress tensor inversion for events of magnitude $\mathrm{M}_{1}>2.5$ [Gephart \& Forsyth, 1984] are shown in Fig. 5b. In the western part of the study area (subareas 2, 3 and $4), \sigma_{1}$ has a N-S trend and progressively increasing dip angles moving northward, whereas the stress ratio $R$ ranges from 0.2 to 0.5 . In the eastern part (subareas 5, 6 and 7), $\sigma_{1}$ invariably shows a NNW-SSE to NW-SE trend, with a stress ratio around 0.6-0.7. In the Internal Zone of the Western Alps (subareas 2 and 4), $\sigma_{3}$ is sub-horizontal and oblique to the orogen trend, and normal to the strike of lower-rank faults that lie at high angle to the Frontal Pennine Fault (e.g., Simplon and Middle Susa Valley faults).

\section{Discussion}

\subsection{Transtension in the Core of the Alps}

Seismotectonic studies published over the past two decades in the Alpine region have suggested that extension is the dominant process in the present-day tectonic activity of the Western Alps [e.g., Champagnac et al., 2004; Selverstone, 2005; Sue et al., 2007]. Focal mechanisms in the Internal Zone would be mainly normal [Eva \& Solarino, 1998; Sue et al., 1999], and areas undergoing extension would be correlated to areas with the thickest crust [Delacou et al., 2004, 2005]. Within this framework, extension in the Internal Alps could be due to isostatic re-equilibration and gravitational collapse of the orogen relative to the foreland areas [Sue et al., 2007]. The late-Alpine tectonic evolution would be thus controlled by buoyancy forces [e.g., Molnar \& Lyon Caen, 1988] rather than Adria-Europe convergence.

Our results, however, show that $\sigma_{3}$ in the Internal Zone of the Western Alps is oblique to the orogen trend, and normal to the strike of lower-rank faults (Fig. 5b). Normal focal mechanisms, which generally have shallow hypocentres, are only found in specific sites of the Internal Zone (Fig. 4a): in the hanging wall of the Simplon Fault, along a major fault bend within the low-grade frontal units of the Aosta Valley, and in a rather limited area to the north of the Stura Fault. Focal mechanisms in correspondence to the highest mountains of the Internal Zone, i.e., the Monte Rosa (MR in Fig. 1c) and the Matterhorn (Dent Blanche unit, DB in Fig. 1c) are exclusively strike-slip (Figs. 4a, 5a). At depths $>12$ km, reverse solutions are dominant along the Piedmont Arc (Fig. 4b), whereas strike-slip mechanisms are predominant in the entire western Alpine area for events of magnitude $M_{1}>4$ (Fig. 5a).

Notably, normal-fault earthquakes are not specific of the Internal Zone. A WNW-ESE belt of extensional events of magnitude $M_{1}<4$ is observed to the south of the Argentera Massif. This extensional belt lies at high angle to the Ligurian coast, which excludes relationships with a possible gravitational collapse of the Ligurian-Provençal margin due to the topographic gradient between the Argentera Massif and the Ligurian oceanic floor [e.g., Larroque et al., 2009]. Instead, it may suggest a pull-apart structure along a higher-rank strike-slip fault, as discussed in Section 6. 
These observations suggest that the mountain range may spread gravitationally at a shallow level. However, spreading may occur intermittently with other earthquakes that are more directly related to plate interactions.

\subsection{Impact of Major Fault Orientation on Seismicity}

Nodal planes for oblique-reverse, strike-slip and oblique-normal events of magnitude $\mathrm{M}_{1}>4$ have rather constant orientations, dominantly NNW-SSE and ENE-WSW (see Fig. 5a). These orientations are common to many major faults mapped in the study area, which may suggest a role exerted by inherited tectonic structures in controlling the seismicity pattern. For example: the Rhone and Chamonix faults in the northern External Zone have an ENEWSW strike; the Parpaillon and Bersezio faults in the southern External Zone, the Briançonnais and Longitudinal faults in the western part of the Internal Zone, and the LisTrana Fault in the eastern part have a NNW-SSE strike. Active NNW-SSE and ENE-WSW faults are revealed in places by alignments of seismic events, e.g. the Rivoli-Marene Deep Fault beneath the western Po Plain and the faults crosscutting or marking the foot of the Ligurian-Provençal margin offshore Liguria (Fig. 3). A relationship between orientation of major faults and nodal planes is evident in the Internal Zone for events of magnitude $M_{1}>4$ (Fig. 5a). Moreover, a relationship is also observed between $\sigma_{3}$ and the orientation of lowerrank faults of the Internal Zone lying at high angle to the orogen trend (Fig. 5b).

Based on available focal mechanisms and choosing the nodal planes parallel to the mapped faults, in the western Po Plain and in the Ligurian-Provençal Basin the NNW-SSE faults are left-lateral whereas in the southern External Zone they are right-lateral. The ENEWSW faults are right-lateral in the northern External Zone, but they are reverse in the Ligurian-Provençal Basin. Other major faults in Fig. 5a have WNW-ESE orientation (e.g., the Stura and Villalvernia-Varzi faults) and NNE-SSW orientation (e.g., the Belledonne and Middle Durance faults). Based on focal mechanisms, these NNE-SSW faults are right-lateral in the northern External Zone and left-lateral in the southern External Zone, whereas the WNW-ESE faults are invariably right-lateral. The contrasting kinematic characteristics observed along major faults sharing the same orientations point to a composite kinematic framework for the western Alpine area, possibly including different tectonic domains characterized by different modalities of strain partitioning.

\subsection{Impact of Exhumed Mantle Rocks on Seismicity}

In the southern Western Alps, seismicity in the different depth ranges is largely controlled by mantle-wedge rocks exhumed to shallow depth beneath the Dora-Maira (Fig. 6). This body of partly-serpentinized mantle-wedge rocks [Solarino et al., 2018] is largely aseismic but clearly outlined, due to rheology contrasts, by earthquake alignments along its boundaries: (i) on the western side, it is marked by a narrow and continuous arcuate belt of earthquakes distributed, in the $12-30 \mathrm{~km}$ depth range, from the Stura Fault to the Lis-Trana Fault (Fig. 3c); (ii) on the eastern side, it is marked by a NNW-SSE alignment of events corresponding to the RivoliMarene Deep Fault; (iii) on the southern side, it is bounded by the Stura Fault.

To the east of the exhumed mantle wedge, in the light of the deep tectonic structure revealed by recent tomography models that document steeply dipping NNW-SSE faults in correspondence with observed earthquake alignments [e.g., Solarino et al., 2018; Lu et al., 2020], focal mechanisms are supportive of a kinematic framework that is relatively constant with depth, and invariably dominated by left-lateral motion and local shortening (Fig. 6). To the west and on top of the exhumed mantle wedge, the seismic style is dominated by reverse mechanisms in the $12-30 \mathrm{~km}$ depth range, and by normal to oblique-normal mechanisms in the $0-12 \mathrm{~km}$ depth range (Fig. 6). 


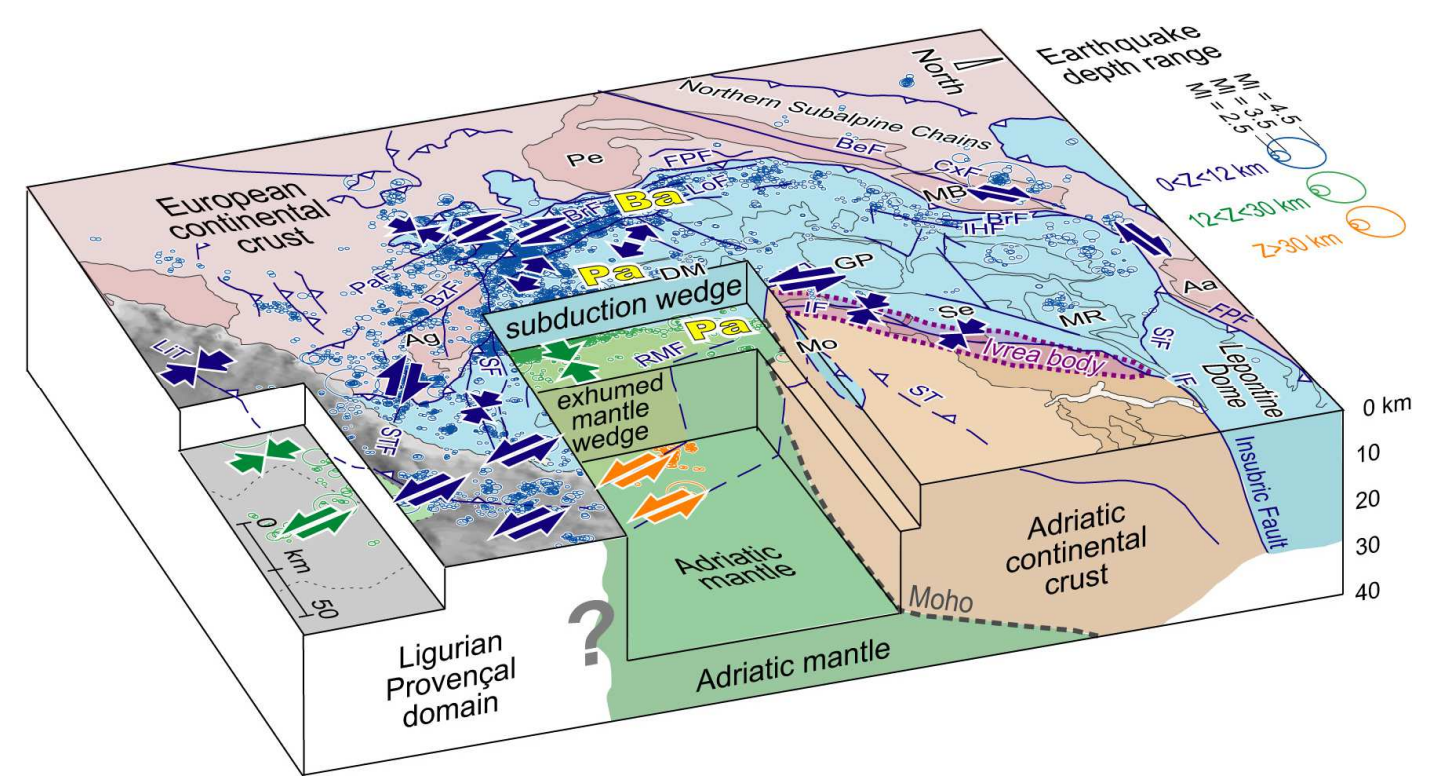

Figure 6. Three-dimensional model of the western Alpine region showing the present-day partitioning of seismic deformation with depth. Arrows summarizing the observations of Fig. 5 are color coded according to the depth range (blue: $0<\mathrm{Z}<12 \mathrm{~km}$; green: $12<\mathrm{Z}<30 \mathrm{~km}$; orange: $\mathrm{Z}>30 \mathrm{~km}$ ). Cross-sections based on Frei et al. (1990), Malusà et al. (2017), Roure et al. (1990), Solarino et al. (2018) and Zhao et al. (2015, 2020). Acronyms as in Fig. 1.

Moving northward along the Ivrea gravity anomaly (Fig. 6), a different seismotectonic framework is observed to the north of the Monferrato Thrust Front. There, reverse focal solutions indicate NW-SE shortening in front of the NE-SW-trending Adriatic mantle slice exhumed during Tethyan rifting. This uplifted Adriatic mantle would act as a rigid buttress transferring deformation towards more external areas of the Alpine orogen, as suggested by 3-D numerical models of continent-continent collision [Liao et al., 2018b].

\section{Summary Seismotectonic Model and Conclusions}

At the transition between the opposite-dipping Alpine and Apenninic slabs, the tectonic structure revealed by geologic and geophysical investigations [e.g., Handy et al., 2010; Malusà et al., 2015; 2017; Solarino et al., 2018; Zhao et al., 2015] appears to control the present-day accommodation of Africa-Eurasia convergence and the resulting seismicity pattern. Convergence rates measured in the study area are generally very low $(<1 \mathrm{~mm} / \mathrm{yr}$, see Sect. 2.4), but increase towards the Central and the Eastern Alps due to counterclockwise rotation of Adria around a pole located in the western Po Plain [Calais et al., 2002; Sánchez et al., 2018; Serpelloni et al., 2007]. We propose that a major role in determining the presentday seismotectonic scenario is likely played by: (i) lithology distribution and orientation of major faults inside the Alpine subduction wedge; (ii) exhumation of mantle-wedge rocks at shallow depth; (iii) tectonic inheritance, for example lithospheric mantle exhumed during Tethyan rifting.

Based on our analysis and previous work [e.g., Bauve et al., 2014; Malusà et al., 2017; Sue et al., 1999], four main seismotectonic domains can be recognized in the western Alpine region (Fig. 7). Domain 1 includes the southern External Zone, the Provençal coast and the adjoining offshore region. There, convergence is partitioned between shortening along NNWdipping thrusts, right-lateral slip along NNW-SSE to WNW-ESE high-angle faults, and left- 
lateral slip along NNE-SSW high-angle faults. A similar deformation pattern was already described by Bauve et al. [2014], who anyway interpreted the observed right-lateral slip along NNW-SSE faults as an effect of counterclockwise rotation of Adria. We remark that no major effect of Adria rotation is expected in Domain 1, because Adria underthrusting beneath the Monferrato implies a change in boundary conditions to the south of latitude $45^{\circ} \mathrm{N}$.

Domain 2 includes the western Po Plain to the south of the Monferrato Thrust Front, the Ligurian Alps and the adjoining offshore region (Fig. 7). In this domain, the kinematic framework is dominated by left-lateral motion along steeply dipping NNW-SSE faults, documented at different depth ranges, from the uppermost crust to the lithospheric mantle, by seismic tomography and earthquake alignments. The observation that these faults are systematically associated to left-lateral focal mechanisms is supportive of faster convergence in Domain 2 compared to Domain 1, which is not evidenced by geodetic data but is clearly revealed by seismotectonic data. Convergence in Domain 2 is also accommodated by rightlateral slip along WNW-ESE faults (e.g., the Villalvernia-Varzi Fault) and by N-S shortening along pre-existing thrust faults. The relative motion between domains 1 and 2 may have favored local extension along ESE-WNW pull-apart structures, as revealed for example by seismicity to the south of the Argentera. The occurrence of anomalously deep events to the south of the Monferrato Thrust Front, but not to the north, may provide seismotectonic evidence against the hypothesis of ongoing northward tearing of the Alpine slab (Fig. 1d).

Figure 7

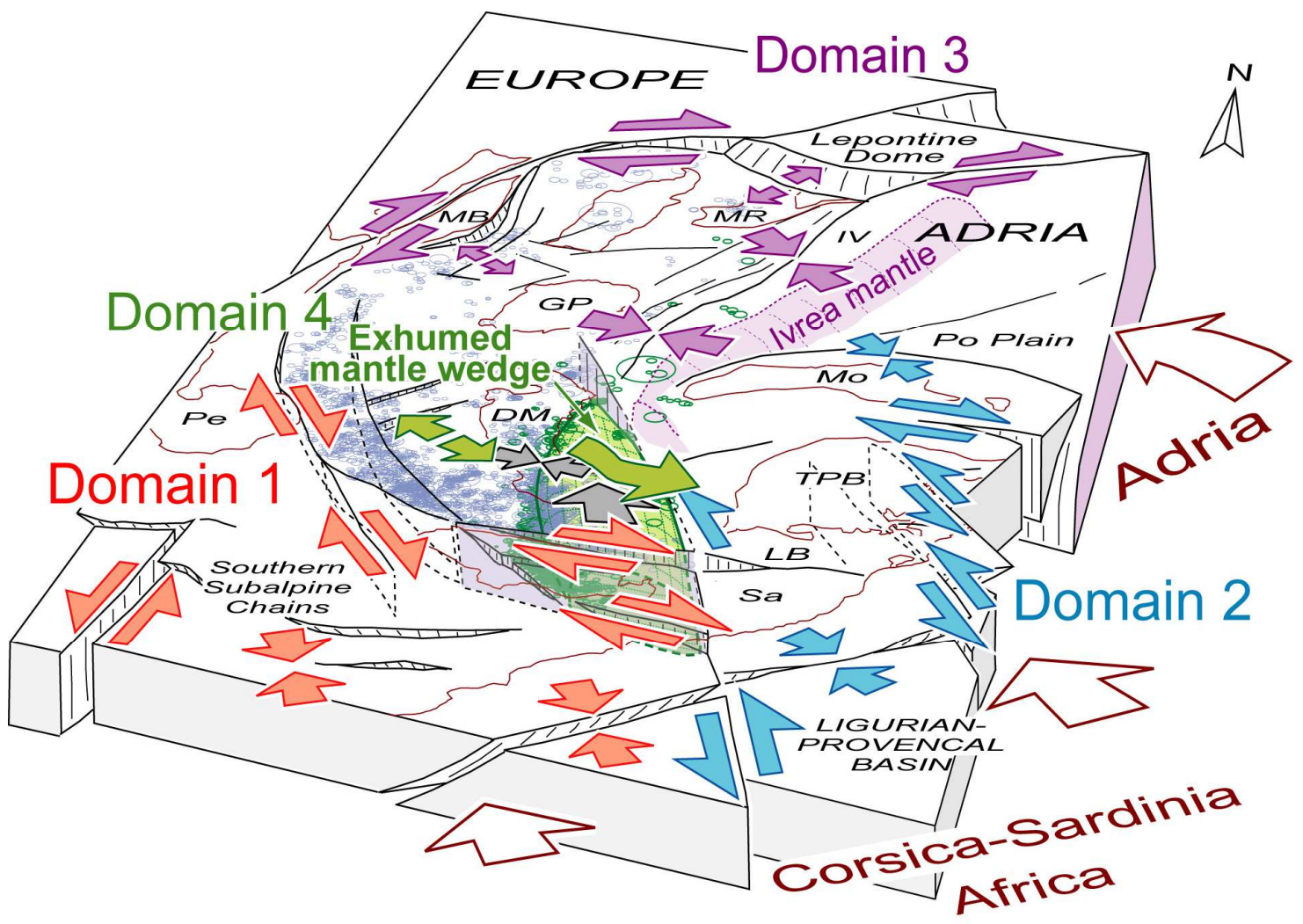

Figure 7. Conceptual seismotectonic model at the transition between the opposite-dipping Alpine and Apenninic slabs (see description in the main text). Earthquakes are only reported for the Alpine Internal Zone (grey $=0-12 \mathrm{~km}$ depth; green $=12-30 \mathrm{~km}$ depth). Acronyms as in Fig 1. The white arrows indicate convergence as inferred from seismotectonic evidence. 
Domain 3 includes the western Po Plain and the External and Internal Zones north of latitude $45^{\circ} \mathrm{N}$. The seismotectonic scenario of Domain 3 is largely determined by the counterclockwise rotation of Adria and by the presence of the Ivrea mantle slice, exhumed during Tethyan rifting, which may have favored the propagation of deformation towards more external areas of the orogen (Fig. 7). There, Adria rotation determines a distributed right-lateral transcurrent regime, and in places localized extension observed for example in the hanging wall of the Simplon Fault. The area in front of the Ivrea mantle slice is instead characterized by NW-SE shortening.

In Domain 4, corresponding to the southern Internal Zone, the seismotectonic framework is largely controlled by the mantle-wedge body exhumed beneath the Dora-Maira (green in Fig. 7). This body is pushed northward due to the component of convergence transmitted across Domain 1. This determines compression in the $12-30 \mathrm{~km}$ depth range, with seismicity clustered along the Piedmont Arc, and a more distributed seismicity in the 0-12 km depth range in the absence of a rigid buttress to the east. The resulting scenario is consistent with available geodetic constraints attesting to negligible E-W convergence across the Western Alps.

This study underlines the major role exerted by the deep tectonic structure in controlling the seismicity pattern at the transition between opposite-dipping slabs. A full understanding of such a complex situation profits from high quality seismic catalogs, and their full integration with available tectonic, geodetic and geodynamic constraints, as well as high-resolution geophysical imagery over the entire plate-boundary zone. Lithology distribution in the subduction wedge, the orientation of major faults within and outside the subduction zone, and the exhumation of mantle rocks at shallow depth, all determine a complex seismotectonic scenario that may be expected in other subduction zones worldwide.

\section{Acknowledgments, Samples, and Data}

The authors have no conflict of interest to declare. Colleagues of the CIFALPS working group are thanked for discussions about the deep structure of the western Alpine region. All data reported in this study are given in the supporting information tables and are archived at http://dx.doi.org/10.17632/5jp698sf2p.1 (Eva et al., 2020). The manuscript benefited from comments from Associate Editor D. Grujic and four anonymous reviewers.

\section{References}

Amato, A., Chiarabba, C., \& Selvaggi, G. (1997). Crustal and deep seismicity in Italy (30 years). Annals of Geophysics, XL (5), 981-993.

Amato, A., \& Mele, F.M. (2008). Performance of the INGV National Seismic Network from 1997 to 2007.

Annals of Geophysics, 51, 2/3.

Barfety, J., C., \& Gidon, M. (1975). La place des failles longitudinales dans la sstructure de Briançonnais oriental (alpes occidentals, France). Comptes Rendus de l'Académie des Sciences Paris, 281, 177-1680.

Baroux, E., Béthoux, N., \& Bellier, O. (2001). Analyses of the stress field in southeastern France from earthquake focal mechanisms. Geophysical Journal International, 145, 336348. https://doi.org/10.1046/j.1365-246x.2001.01362.x

Bauve, V., Plateaux, R., Rolland, Y., Sanchez, G., Bethoux, N., Delouis, B., et al. (2014). Long-lasting transcurrent tectonics in SW Alps evidenced by Neogene to present-day stress fields. Tectonophysics, 621, 85100. https://doi.org/10.1016/j.tecto.2014.02.006

Beaucé, E., Frank, W. B., Paul, A., Campillo, M., \& van der Hilst, R. D. (2019). Systematic detection of clustered seismicity beneath the Southwestern Alps. Journal of Geophysical Research: Solid Earth, 124, 1153111548. https://doi.org/10.1029/2019JB018110 
Bellahsen, N., Jolivet L., Lacombe O., Bellanger M., Boutoux A., Garcia S., et al. (2012). Mechanisms of margin inversion in the external Western Alps: Implications for crustal rheology. Tectonophysics, 560, 62-83. https://doi.org/10.1016/j.tecto.2012.06.022

Beller, S., Monteiller, V., Operto, S., Nolet, G., Paul, A., \& Zhao, L. (2018). Lithospheric architecture of the South-Western Alps revealed by multiparameter teleseismic full-waveform inversion. Geophysical Journal International, 212(2), 1369-1388.

Beltrando, M., Compagnoni, R., \& Lombardo, B. (2010). (Ultra-) High-pressure metamorphism and orogenesis: An Alpine perspective. Gondwana research, 18 (1), 147-166. https://doi.org/10.1016/j.gr.2010.01.009

Bertrand, J. M., Aillères, L., Gasquet, D., \& Macaudière, J. (1996). The Pennine Front zone in Savoie (Western Alps), a review and new interpretations from the Zone Houillère briançonnaise. Eclogae Geologicae Helvetiae, 89, 297-320.

Béthoux, N., Ouillon, G., \& Nicolas, M. (1998). The instrumental seismicity of the western Alps: spatiotemporal patterns analysed with the wavelet transform. Geophysical Journal International, 135 (1), 177-194.

Bigi, G., Cosentino, D., Parotto, M., Sartori, R., \& Scandone, P. (1990). Structural model of Italy and gravity map. Sheets 1-9, 1:500.000. Progetto Finalizzato Geodinamica C.N.R. Quaderni Ricerca Scientifica, 114 (3).

Bistacchi, A., Eva, E., Massironi, M., \& Solarino S. (2000). Miocene to Present kinematics of the NW-Alps: evidences from remote sensing, structural analysis, seismotectonics and thermochronology. Journal of Geodynamics, 30, 205-228. https://doi.org/10.1016/S0264-3707(99)00034-4

Bistacchi, A., Dal Piaz, G.V., Massironi, M., Zattin, M, \& Balestrieri M.L. (2001). The Aosta-Ranzola extensional fault system and Oligocene-Present evolution of the Austroalpine-Penninic wedge in the northwestern Alps. International Journal of Earth Sciences, 90, 654-667. https://doi.org/10.1007/s005310000

Bousquet, R., Goffé, B., Vidal, O., Oberhänsli, R., \& Patriat, M. (2002). The tectono-metamorphic history of the Valaisan domain from the Western to the Central Alps: New constraints on the evolution of the Alps. Bulletin of Geological Society of America, 114, 207-225. https://doi.org/10.1130/00167606(2002)114<3C0207:TTMHOT>3E2.0.CO;2

Buness, H., \& Giese, P. (1990). A crustal section through the northwestern Adriatic plate. In: R. Freeman, P. Giese, and St. Mueller (eds), The European Geotraverse: Integrative Studies, European Science Foundation, Strasbourg, pp. 297-304.

Calais, E., Noquet, J.M, Jounne F., \& Tardy, M. (2002). Current strain regime in the Western Alps from continuos Global Positioning System measurements, 1996-2001. Geology, 30, 651-654. https://doi.org/10.1130/0091-7613(2002)030<0651:CSRITW>2.0.CO;2

Campani, M., Mancktelow, N.S., Seward, D., Rolland, Y., Müller, W., \& Guerra, I. (2010). Geochronological evidence for continuous exhumation through the ductile-brittle transition along a crustal-scale low-angle normal fault (Simplon Fault Zone, Central Alps). Tectonics, 29 (3), TC3002, https://doi.org/10.1029/2009TC002582

Carminati, E., \& Doglioni, C. (2012). Alps Vs. Apennines: The paradigm of a tectonically asymmetric Earth. Earth Science Reviews, 112, 67-96. https://doi.org/10.1016/ j.earscirev.2012.02.004

Cattaneo, M., Augliera, P., Spallarossa, D., \& Eva, C. (1997). Reconstruction of seismogenetic structures by multiplet analysis: An example of Western Liguria, Italy. Bulletin of the Seismological Society of America, 87 (4), 971-986.

Champagnac, J.D., Sue, C., Delacou, B., \& Burkhard, M. (2004). Brittle deformation in the inner northwestern Alps: From early orogen - parallel extrusion to late orogen - perpendicular collapse. Terra Nova, 16, $232-242$. https://doi.org/10.1111/j.1365-3121.2004.00555.x

Champagnac, J.D., Molnar, P., Anderson, R.S., Sue C., \& Delacou B. (2007). Quaternary erosion-induced isostatic rebound in the Western Alps. Geology, 35 (3),195-198. https://doi.org/10.1130/G23053A.1

Chaumillon, E., Deverchere, J., Réhault, J.P., \& Gueguen, E. (1994). Réactivation tectonique et flexure de la marge continentale Ligure (Méditerranée Occidentale). Comptes Rendus de l Académie des Sciences Paris, II Series, 319, 615-682

Chiarabba, C., Javane, J., \& Di Stefano, R. (2005). A new view of Italian seismicity using 20 years of instrumental recordings. Tectonophysics, 395 (3-4), 251-268. https://doi.org/10.1016/j.tecto.2004.09.013. 
Collombet, M., Thomas, J.C., Chauvin, A., Tricart, P., Bouillin, J. P., \& Gratier, J.P. (2002). Counterclockwise rotation of the western Alps since the Oligocene: New insights from paleomagnetic data. Tectonics, 21 (4). https://doi.org/10.1029/2001TC901016

Cronin, V.S., (2010). A primer on focal mechanism solutions for geologists. Science Education Resource Center, Carleton College, accessible via http://serc.carleton.edu/files/NAGTWorkshops/structure04/Focal_mechanism_primer.pdf.

Delacou, B., Burkhard, M., Champagnac, L.D., \& Sue, C. (2004). Present-day geodynamics in the bend of the Western and Central Alps as constrained by earthquake analysis. Geophysical Journal International, 158 (2). https://doi.org/10.1111/j.1365-246X.2004.02320.x

Delacou, B., Sue, C., Champagnac, J.D., \& Burkhard, M., (2005). Origin of the current stress field in the western/central Alps: Role of gravitational re-equilibration constrained by numerical modelling. Geological Society London Special Publications, 243(1). https://doi.org/10.1144/GSL.SP.2005.243.01.19.

Dewey, J.F., Helman, M.L., Knott, S.D., Tuerco, E., \& Hutton, D.H.W. (1989). Kinematics of the western Mediterranean. Geological Society London Special Publications, 45 (1), 265-283. https://doi.org/10.1144/GSL.SP.1989.045.01.15

Douilly, R., Haase, J. S., Ellsworth, W. L., Bouin, M. P., Calais, E., Symithe, S. J., ... \& Meremonte, M. E. (2013). Crustal structure and fault geometry of the 2010 Haiti earthquake from temporary seismometer deployments. Bulletin of the Seismological Society of America, 103(4), 2305-2325.

Dumont, T., Simon-Labric, T., Authemayou, C., \& Heymes T. (2011). Lateral termination of the north-directed Alpine orogeny and onset of westward escape in the Western Alpine Arc: Structural and sedimentary evidence from the external zone. Tectonics, 30 (5). https://doi.org/10.1029/2010TC002836

Eva, C., Barani, S., Carenzo, G., De Ferrari, R., Eva, E., Ferretti, G., et al., (2010). 30 years of seismicity in the south-western Alps and northern Apennines as recorded by the regional seismic network of Northwestern Italy. Atti del XXIX Convegno GNGTS, 50-53.

Eva, E., Solarino, S., Eva, C., \& Neri, G. (1997). Stress tensor orientation derived from fault plane solutions in the southwestern Alps. Journal of Geophysical Research, 102 (B4), 8171-8185.

Eva, E., \& Solarino, S. (1998). Variations of stress directions in the western Alpine arc. Geophysical Journal International, 135, 438-448.

Eva, E., Pastore, S., \& Deichmann, N. (1998). Evidence for ongoing extensional deformation in the western swiss Alps and thrust-faulting in the sothwestern alpine foreland. Journal of Geodynamics, 26 (1), 27-43.

Eva, E., Solarino, S., \& Spallarossa, D. (2001). Seismicity and crustal structure beneath the western Ligurian Sea derived from local earthquake tomography. Tectonophysics, 339, 495-510. https://doi.org/10.1016/S00401951(01)00106-8

Eva, E., Malusà, M.G., \& Solarino, S. (2015). Seismotectonic picture of the inner southern Western Alps based on the analysis of anomalously deep earthquakes Tectonophysics, 661, 190-199. http://dx.doi.org/10.1016/j.tecto.2015.08.040

Eva, E., Malusà, M.G., \& Solarino, S. (2016). Seismotectonic picture of the Argentera-Mercatour Massif. Atti del XXXV Convegno GNGTS, 127-129. ISBN: 978-88-940442-7-0

Eva, E., Malusà, M.G., \& Solarino, S. (2020). Seismotectonics at the transition between opposite-dipping slabs (western Alpine region) - DATASET, Mendeley Data, V1, doi: 10.17632/5jp698sf2p.1

Faccenna, C., Becker, T.W., Lucente, F.P., Jolivet, L., \& Rossetti, F. (2001). History of subduction and back-arc extension in the Central Mediterranean. Geophysical Journal International, 145 (3). https://doi.org/10.1046/j.0956-540x.2001.01435.x

Fantoni, R., Bersezio, R., \& Forcella, F. (2004). Alpine structure and deformation chronology at the Southern Alps-Po Plain border Lombardy. Bollettino della Societa Geologica Italiana, 123, 463-476.

Frei, W., Heitzmann, P., \& Lehner, P. (1990). Swiss NFP-20 research program of the deep structure of the Alps. Mémoires de la Société géologique de France, 156, 29-46.

Gattacceca, J., Deino, A., Rizzo, R., Jones, D. S., Henry, B., Beaudoin, B., et al. (2007). Miocene rotation of Sardinia: New paleomagnetic and geochronological constraints and geodynamic implications, Earth and Planetary Science Letters, 258, 359- 377. https://doi.org/10.1016/j.eps1.2007.02.003 
Gephart, J.W., \& Forsyth, D.W. (1984). An improved method for determining the regional stress tensor using earthquake focal mechanism data: Application to the San Fernando Earthquake Sequence. Journal of Geophysical Research, Solid Earth, 89, B11, 9305-9320. https://doi.org/10.1029/JB089iB11p09305

Giacomuzzi, G., Chiarabba, C., \& De Gori, P. (2011). Linking the Alps and Apennines subduction systems: new constraints revealed by high-resolution teleseismic tomography. Earth and Planetary Science Letters, 301, 53154. https://doi.org/10.1016/j.eps1.2010.11.033

Giardini, D., Grünthal, G., Shedlock, K.M., \& Zhang, P. (1999). The GSHAP Global Seismic Hazard Map, Annals of Geophysics, 42 (6), 1215-1223.

Giglia, G., Capponi, G., Crispini, L., \& Piazza, M. (1996). Dynamics and seismotectonics of the West-Alpine arc. Tectonophysics, 267, 143-175. https://doi.org/10.1016/S0040-1951(96)00093-5

Godano, M., Larroque, C., Bertrand, E., Courboulex, F., Deschamps, A., Salichon, J., et al. (2013). The October-November 2010 earthquake swarm near Sampeyre (Piedmont region, Italy): A complex multicluster sequence. Tectonophysics, 608, 97-111. https://doi.org/10.1016/j.tecto.2013.10.010

Guillot, S., Schwartz, S., Hattori, K., Auzende, A., \& Lardeaux, J. (2004). The Monviso ophiolitic massif (Western Alps), a section through a serpentinite subduction channel. Journal of the Virtual Explorer, 16, pp. 17. https://doi.org/10.3809/jvirtex.2004.00099

Gurlay, P., \& Ricou, L.E. (1983). Le jeu décrochant dextre tardif de la suture de Chamonix (Alpes françaises et suisses). Comptes Rendus de l'Académie des Sciences Paris, Series II, 296, 927-932.

Handy, M.R, Schmid, S.M., Bousquet, R., Kissling, E., \& Bernoulli, D. (2010). Reconciling plate-tectonic reconstructions of Alpine Tethys with the geological-geophysical record of spreading and subduction in the Alps. Earth Science Reviews, 102 (3-4), 121-158. https://doi.org/10.1016/j.earscirev.2010.06.002

Hua, Y., Zhao, D., \& Xu, Y. (2017). P wave anisotropic tomography of the Alps. Journal of Geophysical Research: Solid Earth, 122(6), 4509-4528.

INGV National Central Seismic Network (2006). Seismological Data Centre - Rete Sismica Nazionale (RSN), Istituto Nazionale di Geofisica e Vulcanologia (INGV), Italy. https://doi.org/10.13127/SD/X0FXNH7QFY

Jenatton, L., Guiguet, R., Thouvenot, F., \& Daix, N. (2007). The 16,000-event 2003-2004 earthquake swarm in Ubaye (French Alps). Journal of Geophysical Reasearch, 112, B11304. https://doi.org/10.1029/2006JB004878

Ji, W. Q., Malusà, M.G., Tiepolo, M., Langone, A., Zhao, L., \& Wu, F.Y. (2019). Synchronous Periadriatic magmatism in the Western and Central Alps in the absence of slab breakoff. Terra Nova, 31 (2), 120-128. https://doi.org/10.1111/ter.12377

Jolivet, L., Faccenna, C., Goffé, B., Burov, E., \& Agard, P. (2003). Subduction tectonics and exhumation of high-pressure metamorphic rocks in the Mediterranean orogens. American Journal of Science, 303, 353-409. https://doi.org/10.2475/ajs.303.5.353

Kästle, E. D., El-Sharkawy, A., Boschi, L., Meier, T., Rosenberg, C., Bellahsen, N., ... \& Weidle, C. (2018). Surface Wave Tomography of the Alps Using Ambient-Noise and Earthquake Phase Velocity Measurements. Journal of Geophysical Research: Solid Earth, 123(2), 1770-1792.

Kästle, E. D., Rosenberg, C., Boschi, L., Bellahsen, N., Meier, T., \& El-Sharkawy, A. (2020). Slab break-offs in the Alpine subduction zone. International Journal of Earth Sciences, 1-17.

Kissling, E. (1988). Geotomography with local earthquake data. Reviews of Geophysics, 26, 4, 659, doi: 10.1029/RG026i004p00659.

Kissling E, \& Spakman, W. (1996). Interpretation of tomographic images of uppermost mantle structure: Examples from the western and central Alps. Journal of Geodynamics, 21, 97-111.

Lahr, J.C. (1999). HYPOELLIPSE/VAX: a computer program for determining local earthquake hypocentral parameters, magnitude and first-motion pattern (Y2K Compliant Version), Version 1.0. United States Geological Survey Open File Report, 99-23 (On-Line Edition).

Lardeaux, J.M., Schwartz, S., Tricart P., Paul, A., Guillot, S., Béthoux, N., \& Masson, M. (2006). A crustal scale cross section of the south western Alps combining geophysical and geological imagery. Terra Nova, 18 (6), 412-422. https://doi.org/10.1111/j.1365-3121.2006.00706.x 
Larroque, C., Béthoux, N., Calais, E., Courboulex, F., Deschamps, A., Déverchère, J., et al. (2001). Active deformation at the junction between southern French Alps and Ligurian basin. Netherlands Journal of Geosciences/Geologie en Mijnbouw, 80 (3-4), 255-272. https://doi.org/10.1017/S0016774600023878

Larroque, C., Deloui, B., Godel, B., \& Nocquet J.M. (2009). Active deformation at the southwestern AlpsLigurian basin junction (France-Italy boundary): evidence for recent change from compression to extension in the Argentera massif. Tectonophysics, 467, 1-4. https://doi.org/10.1016/j.tecto.2008.12.013

Larroque, C., Mercier de Lépinay, B., \& Migeon, S. (2011). Morphotectonic and fault-earthquake relationships along the northern Ligurian margin (western Mediterranean) based on high resolution, multibeam bathymetry and multichannel seismic-reflection profiles. Marine Geophysical Researches, 32, 163-179. https://doi.org/10.1007/s11001-010-9108-7

Laubscher, H.P. (1988). Material balance in Alpine orogeny. Bulletin of Geological Society of America, 100, 1313-1328.

Liao, J., Malusà, M.G., Zhao, L., Baldwin, S., Fitzgerald, P., \& Gerya, T. (2018a). Divergent plate motion drives rapid exhumation of (ultra)high pressure rocks. Earth and Planetary Science Letters, 491, 67-80. https://doi.org/10.1016/j.epsl.2018.03.024

Liao, J., Gerya, T., \& Malusà, M.G. (2018b). 3D modeling of crustal shortening influenced by along-strike lithological changes: Implications for continental collision in the Western and Central Alps. Tectonophysics, 746, 425-438. https://doi.org/10.1016/j.tecto.2018.01.031

Lippitsch, R., Kissling, E., \& Ansorge, J. (2003). Upper mantle structure beneath the Alpine orogen from highresolution teleseismic tomography. Journal of Geophysical Research: Solid Earth 108.B8

Lu, Y., Stehly, L., Brossier, R., Paul, A., \& AlpArray Working Group (2020). Imaging Alpine crust using ambient noise wave-equation tomography. Geophysical Journal International, 222(1), 69-85.

Maffione, M., Speranza, F., Faccenna, C., Cascella, A., Vignaroli, G., \& Sagnotti, L. (2008). A synchronous Alpine and Corsica-Sardinia rotation. Journal of Geophysical Research Atmospheres, 113 (B3). https://doi.org/10.1029/2007JB005214

Malusà, M.G. (2004), Post-metamorphic evolution of the Western Alps: kinematic constraints from a multidisciplinary approach (geological mapping, mesostructural analysis, fission-track dating, fluid inclusion analysis). Published PhD Thesis, 320 pp., CNR-IGG - University of Turin, Litografia Geda, Nichelino (TO), Italy.

Malusà, M. G., \& Balestrieri, M. L. (2012). Burial and exhumation across the Alps-Apennines junction zone constrained by fission-track analysis on modern river sands. Terra Nova, 24(3), 221-226. https://doi:10.1111/j.1365-3121.2011.01057.x

Malusà, M.G., Polino, R., Zattin, M., Bigazzi, G., Martin, S., \& Piana, F. (2005a). Miocene to Present differential exhumation in the Western Alps: Insights from fission track thermochronology. Tectonics, 24, TC3004, 1-23. https://doi:10.1029/2004TC001782

Malusà, M. G., Polino, R., \& Martin, S. (2005b). The Gran San Bernardo nappe in the Aosta valley (western Alps): a composite stack of distinct continental crust units. Bulletin de la Société géologique de France, 176(5), 417-431. https://doi.org/10.2113/176.5.417

Malusà, M. G., Philippot, P., Zattin, M., \& Martin, S. (2006). Late stages of exhumation constrained by structural, fluid inclusion and fission track analyses (Sesia-Lanzo unit, Western European Alps). Earth and Planetary Science Letters, 243(3-4), 565-580. https:// doi:10.1016/j.eps1.2005.12.030

Malusà, M.G., Polino, R., \& Zattin, M. (2009). Strain partitioning in the axial NW Alps since the Oligocene. Tectonics, 28, TC3005, 1-26. https:// doi:10.1029/ 2008TC002370

Malusà, M. G., Faccenna, C., Garzanti, E., \& Polino, R. (2011). Divergence in subduction zones and exhumation of high pressure rocks (Eocene Western Alps). Earth and Planetary Science Letters, 310(1-2), 2132. https://doi:10.1016/j.epsl.2011.08.002

Malusà, M.G., Faccenna, C., Baldwin, S.L., Fitzgerald, P.G., Rossetti, F., Balestrieri, M.L., Danišík, M., Ellero, A., Ottria, G., \& Piromallo, C. (2015). Contrasting styles of (U)HP rock exhumation along the Cenozoic AdriaEurope plate boundary (Western Alps, Calabria, Corsica). Geochemistry, Geophysics, Geosystems, 16(6), 17861824. https://doi: 10.1002/2015GC005767 
Malusà, M.G., Anfinson, O.A., Dafov, L.N., \& Stockli, D.F. (2016a). Tracking Adria indentation beneath the Alps by detrital zircon U-Pb geochronology: Implications for the Oligocene-Miocene dynamics of the Adriatic microplate. Geology, 44, 155-158. https://doi: 10.1130/G37407.1

Malusà, M.G., Danišík, M., \& Kuhlemann, J. (2016b). Tracking the Adriatic-slab travel beneath the Tethyan margin of Corsica-Sardinia by low-temperature thermochronometry. Gondwana Research, 31, 135-149. https:// doi:10.1016/j.gr.2014.12.011

Malusà, M.G., Zhao, L., Eva, E., Solarino, S., Paul, A., Guillot, S., Schwartz, S., Dumont, T., Aubert, C., Salimbeni, S., Pondrelli, S., Wang, Q., \& Zhu, R. (2017). Earthquakes in the Western Alpine mantle wedge. Gondwana Research, 44, 89-95. https://doi: 10.1016/j.gr.2016.11.012

Malusà, M.G., Frezzotti, M.L., Ferrando, S., Brandmayr, E., Romanelli, F., \& Panza, G.F. (2018). Active carbon sequestration in the Alpine mantle wedge and implications for long-term climate trends. Scientific Reports, 8 , 4740. https://doi:10.1038/s41598-018-22877-7

Mancktelow, N. (1985). The Simplon Line: a major displacement zone in the western Lepontine Alps, Eclogae Geologicae Helvetiae, 78, 73-96. https://doi.org/10.5169/seals-165644

Massa, M., Eva, E., Spallarossa, D., \& Eva, C. (2006). Detection of earthquake clusters on the basis of waveform similarity: An application in the Monferrato region (Piedmont, Italy). Journal of Seismology, 10, 1-22. https://doi:10.1007/s10950-006-2840-4

McClusky, S., Reilinger, R., Mahmoud, S., Ben Shari, D., \& Tealeb, A. (2003). GPS constraints on Africa (Nubia) and Arabia plate motions. Geophysical Journal International, 155, 126-138. https://doi.org/10.1046/j.1365-246X.2003.02023.x

Michelini, A., \& Lomax, A. (2004). The effect of velocity structure errors on double-difference earthquake location. Geophysical Research Letters, 31, L09602. doi:10.1029/2004GL019682.

Molli, G., \& Malavieille, J. (2011). Orogenic processes and the Corsica/Apennines geodynamic evolution: insights from Taiwan. International Journal of Earth Sciences, 100 (5), 1207-1224. https://doi.org/10.1007/s00531-010-0598-y

Molnar, P., \& Lyon-Caen., H. (1988). Some simple physical aspects of the support, structure and evolution of mountain belts. Geological Society of Special Papers, 218, 179-207.

Mosca, P., Polino, R., Rogledi, S., \& Rossi, M. (2010). New data for the kinematic interpretation of the AlpsApennines junction (Northwestern Italy). International Journal of Earth Sciences, 99 (4), 833-849. https://doi.org/10.1007/s00531-009-0428-2

Müller, W., Prosser, G., Mancktelow, N.S., Villa, I.M., Kelley, S.P., Viola, G., et al. (2001). Geochronological constraints on the evolution of the Periadriatic Fault System (Alps). International Journal of Earth Sciences, 90, 623- 653 https://doi.org/10.1007/s005310000187

Nicolas, A., Hirn, A., Nicolich, R., Polino, R. \& ECORS-CROP Working Group (1990a). Lithospheric wedging in the western Alps inferred from the ECORS-CROP traverse. Geology, 18, 587-590.

Nicolas, M., Santoire, J.P., \& Delpech, P.Y. (1990b). Intraplate seismicity: new seismotectonic data in Western Europe. Tectonophysics, 179, 27-53.

Nocquet, J.M. (2012). Present-day kinematics of the Mediterranean: A comprehensive overview of GPS results. Tectonophysics, 579, 220-242. https://doi.org/10.1016/j.tecto.2012.03.037

Nocquet, J.M, \& Calais, E. (2003). Crustal velocity field of western Europe from permanent GPS array solutions, 1996-2001. Geophysical Journal International, 154 (1), 72-88. https://doi.org/10.1046/j.1365246X.2003.01935.x

Nocquet, J.M., \& Calais, E. (2004). Geodetic measurements of crustal deformation in the western Mediterranean and Europe. Pure and Applied Geophysics, 161 (3), 661-681. https://doi.org/10.1007/s00024-003-2468-z

Nocquet, J.M., Willis, P., \& Garcia, S. (2006). Plate kinematics of Nubia-Somalia using a combined DORIS and GPS solution. Journal of Geodesy, 80 (8-11), 591- 607. https://doi.org/10.1007/s00190-006-0078-0

Nocquet, J. M., Sue, C., Walpersdorf, A., Tran, T., Lenôtre, N., Vernant, P., et al. (2016). Present-day uplift of the western Alps. Scientific Reports, 6 (1), 28404. https://doi.org/10.1038/srep28404 
Perrone, G., Eva, E., Solarino, S., Cadoppi, P., Balestro, G., Fioraso, G., et al. (2010). Seismotectonic investigations in the inner Cottian Alps (Italian Western Alps): an integrated approach. Tectonophysics, 496, 116. http://doi.org/10.1016/j.tecto.2010.09.009

Perrone, G., Eva, E., Cadoppi, P., Solarino, S., \& Fioraso, G. (2011). Seismotectonics of a low-deformation area: the central Western Alps (Italy). Bollettino di Geofisica Teorica ed Applicata, 52 (2), 261-281. https://doi.org/10.4430/bgta0004

Pieri, M., \& Groppi, G. (1981). Subsurface Geological Structure of the Po Plain, Italy. Progetto Finalizzato Geodinamica, Agip-CNR, publ. 414

Piromallo, C., \& Morelli, A. (2003). P wave tomography of the mantle under the Alpine-Mediterranean area. Journal of Geophysical Research, 108 (B2), 2065. https://doi.org/10.1029/2002JB001757

Polino, R., Malusà, M.G., Martin, S., Carraro, F., Gianotti, F., et al. (2015). Foglio 090 Aosta e Note illustrative, Carta Geologica d'Italia alla scala 1:50.000, ISPRA.

Pondrelli, S., Salimbeni, S., Ekström, G., Morelli, A., Gasperini, P., \& Vannucci, G. (2006). The Italian CMT dataset from 1977 to the present. Physics of the Earth and Planetary Interiors, 159 (3-4), 286-303. https://doi.org/10.1016/j.pepi.2006.07.008

Reasenberg, P.A., \& Oppenheimer, D. (1985). FPFIT, FPPLOT and FPPAGE: FORTRAN computer programs for calculating and displaying earthquake fault-plane solutions. United States Geological Survey Open File Report, 85-739, pp. 109.

RESIF (1995). RESIF-RLBP French Broad-band network, RESIF-RAP strong motion network and other seismic stations in metropolitan France [Data set]. RESIF - Réseau Sismologique et géodésique Français. https://doi.org/10.15778/RESIF.FR

Ricou, L.E. (1981). Glissement senestre des Alpes penniques le long de la bordure de l'Argentera: son role dans le jeu de l'arc alpin. Comptes Rendus de l'Académie des Sciences Paris, 292, 1305 -1308.

RNSI - University of Genoa (1967). Regional Seismic Network of North Western Italy. International Federation of Digital Seismograph Networks. https://doi.org/10.7914/SN/GU

Rothé, J.P. (1941). Les séismes des Alpes françaises en 1938 et la sismicité des Alpes occidentales, Annales de l'Institut de Physique du Globe Strasbourg, 3, 1-105.

Roure, F., P. Heitzmann, and R. Polino (Eds.) (1990). Deep Structures of the Alp. Mem. Soc. Geol. Fr., 156, 367 pp.

Salimbeni, S., Malusà, M.G., Zhao, L., Guillot, S., Pondrelli, S., Margheriti, L., et al. (2018). Active and fossil mantle flows in the western Alpine region unravelled by seismic anisotropy analysis and high-resolution $P$ wave tomography. Tectonophysics, 731-732, 35-47. https://doi.org/10.1016/j.tecto.2018.03.002

Sanchez, G., Rolland, Y., Schreiber, D., Giannerini, G., Corsini, M., \& Lardeaux, J.M. (2010). The active fault system of SW Alps. Journal of Geodynamics, 49, 296-302. https://doi.org/10.1016/j.jog.2009.11.009

Sanchez, G., Rolland, Y., Jolivet, M., Brichau, S., Corsini, M., \& Carter, A. (2011). Exhumation controlled by transcurrent tectonics: the Argentera-Mercantour massif (SW Alps). Terra Nova, 23, 116-126. https://doi.org/10.1111/j.1365-3121.2011.00991.x

Sánchez, L., Völksen, C., Sokolov, A., Arenz, H., \& Seitz, F. (2018). Present-day surface deformation of the Alpine region inferred from geodetic techniques. Earth System Science Data, 10, 1503-1526.

Scafidi, D., Solarino, S., \& Eva, C. (2006). Structure and properties of the Ivrea body and of the AlpsApennines systems as revealed by local earthquake tomography. Bollettino di Geofisica Teorica ed Applicata, 47, 497-514.

Scafidi, D., Solarino, S., \& Eva, C. (2009). P wave seismic velocity and Vp/Vs ratio beneath the Italian Peninsula from local earthquake tomography. Tectonophysics, 465, 1-23. https://doi.org/10.1016/j.tecto.2008.07.013

Schmid, S.M., \& Kissling, E. (2000). The arc of the Western Alps in the light of geophysical data on deep crustal structure, Tectonics, 19, 62- 85. https://doi.org/10.1029/1999TC900057

Schmid, S. M., Fugenschuh, B., Kissling. E. \& Schuster, R. (2004). Tectonic map and overall architecture of the Alpine orogen. Eclogae Geologicae Helvetiae, 97, 93-117. https://doi.org/10.1007/s00015-004-1113-X 
1002 Schmid, S. M., Kissling, E., Diehl, T., van Hinsbergen, D. J., \& Molli, G. (2017). Ivrea mantle wedge, arc of the Geosciences, 110(2), 581-612.

1005 Schwartz, S., Lardeaux, J.M., Tricart, P., Guillot, S., \& Labrin, E. (2007). Diachronous exhumation of HP-LT metamorphic rocks from south-western Alps: Evidence from fission-track analysis. Terra Nova, 19 (2), 133140. https://doi.org/10.1111/j.1365-3121.2006.00728.x

1008

1009

1010

1011

1012

1013

1014

1015

1016

1017

1018

1019

1020

1021

1022

1023

1024

1025

1026

1027

1028

1029

1030

1031

1032

1033

1034

1035

1036

1037

1038

1039

1040

1041

1042

1043

1044

1045

1046

1047

1048

1049

1050

1051

1052
Schwartz, S., Gautheron, C., Audin, L., Dumont, T., Nomade, J., \& Barbarand, J. (2017). Foreland exhumation controlled by crustal thickening in the Western Alps. Geology, 45 (2), 139-142. https://doi.org/10.1130/G38561.1

Scognamiglio L., Tinti, E., \& Michelini, A. (2009). Real-time determination of seismic moment tensor for italian region. Bulletin of Geological Society of America, 99 (4), 2223-2242. https://doi.org/10.1785/0120080104

Selverstone, J. (2005). Are the Alps collapsing? Annual Review of Earth and Planetary Sciences, 33, 113-132. https://doi.org/10.1146/annurev.earth.33.092203.122535

Serpelloni, E., Vannucci, G., Pondrelli, S., Argnani, A., Casula, G., Anzidei, M., et al. (2007). Kinematics of the Western Africa-Eurasia plate boundary from focal mechanisms and GPS data. Geophysical Journal International., 169 (3), 1180-1200. https://doi.org/10.1111/j.1365-246X.2007.03367.x

Serpelloni, E., Vannucci, G., Anderlini, L., \& Bennett, R.A. (2016). Kinematics, seismotectonics and seismic potential of the eastern sector of the European Alps from GPS and seismic deformation data. Tectonophysics, 688, 157-181. https://doi.org/10.1016/j.tecto.2016.09.026

Solarino, S., Malusà, M.G., Eva, E., Guillot, S., Paul, A., Schwartz, S., et al. (2018). Mantle wedge exhumation beneath the Dora-Maira (U)HP dome unravelled by local earthquake tomography (Western Alps). Lithos, 296299, 623-636. https://doi.org/10.1016/j.lithos.2017.11.035

SSS - Swiss Seismological Service (SED) at ETH Zurich (1983). National Seismic Networks of Switzerland; ETH Zürich. Other/Seismic Network. https://doi.org/10.12686/sed/networks/ch

Sternai, P., Sue, C., Husson, L., Serpelloni, E., Becker, T.W., Willett, S., et al. (2019). Present-day uplift of the European Alps: Evaluating mechanisms and models of their relative contributions. Earth-Science Reviews, 190. https://doi.org/10.1016/j.earscirev.2019.01.005

Sue, C., \& Tricart, P. (1999). Late Alpine brittle extension above the Frontal Pennine Thrust near Briançon, Western Alps. Eclogae Geologicae Helvetiae, 92, 171- 181.

Sue, C., \& Tricart, P. (2003). Neogene to ongoing normal faulting in the inner Western Alps: A major evolution of the late alpine tectonics. Tectonics, 22 (5), 1050. https://doi.org/10.1029/2002TC001426

Sue, C., Thouvenot, F., Frechét, J., \& Tricart, P. (1999). Widespread extension in the core of the western Alps revealed by earthquake analysis. Journal of Geophysical Research, 104, 25,611-25,622.

Sue, C., Delacou, B., Champagnac, J. D., Allanic, C., Tricart, P., \& Burkhard, M. (2007). Extensional neotectonics around the bend of the western/central Alps: An overview. International Journal of Earth Sciences, 96 (6), 1101- 1129. https://doi.org/10.1007/s00531-007-0181-3

Sun, W., Zhao, L., Malusà, M.G., Guillot, S., \& Fu, L.Y. (2019). 3-D Pn tomography reveals continental subduction at the boundaries of the Adriatic microplate in the absence of a precursor oceanic slab. Earth and Planetary Science Letters, 510, 131-141. https://doi.org/10.1016/j.epsl.2019.01.012

Tapponnier, P., (1977). Evolution tectonique du système alpin en Méditarranée: poinçonnement et écrasement rigide - plastique. Bullettin de la Société Géologique de France, 19, 437-460.

Thouvenot, F., Frechét, J., Jenatton, L., \& Gamond, J.F. (2003). The Belledonne Border Fault: identification of an active seismic strike-slip fault in the western Alps. Geophysical Journal International, 155, 174-192. http://doi.org/10.1046/j.1365-246X.2003.02033.x

Tricart, P. (2004). From extension to transpression during the final exhumation of the Pelvoux and Argentera massifs, Western Alps, Eclogae Geologicae Helvetiae, 97, 429- 439. https://doi.org/10.1007/s00015-004-11381

Tricart, P., Lardeaux, J.M., Schwartz, S., \& Sue, S. (2006). The late extension in the inner western Alps: A synthesis along the south-Pelvoux transect. Bulletin de la Societe Geologique de France, 177 (6), 299-310. https://doi.org/10.2113/gssgfbull.177.6.299 
1053

1054

1055

1056

1057

1058

1059

1060

1061

1062

1063

1064

1065

1066

1067

1068

1069

1070

1071

1072

1073

1074
Turino, C., Scafidi, D., Eva, E., \& Solarino, S. (2009). Inferences on active faults at the Southern Alps-Liguria basin junction from accurate analysis of low energy seismicity. Tectonophysics, 475, 470-479. https://doi.org/10.1016/j.tecto.2009.06.007

Vialon, P. (1990). Deep Alpine structures and geodynamic evolution: an introduction and outline of a new interpretation. In Deep structure of the Alps, eds Roure, F., Heitzmann,P. \& Polino, R., Mem. Soc. Geol. Fr., 156; Mem. Soc. Geol. Suisse, 1; Vol. Spec. Soc. Geol. It.,1, 7-14.

Waldhauser, F., \& Ellsworth, W.L. (2000). A double-difference earthquake location algorithm: method and application to the northern Hayward fault, California. Bulletin of Geological Society of America, 90, 1353-1368. https://doi.org/10.1785/0120000006

Walpersdorf, A., Pinget, L., Vernant, P., Sue, C., Deprez, A., \& the RENAG team (2018). Does long-term GPS in the Western Alps finally confirm earthquake mechanisms? Tectonics, 37, 3721-3737. https://doi.org/10.1029/2018TC005054

Zhao, L., Paul, A., Guillot, S., Solarino, S., Malusà, M.G., Zheng, T., Aubert, C., Salimbeni, S., Dumont, T., Schwartz, S., Zhu, R., \& Wang, Q. (2015). First seismic evidence for continental subduction beneath the western Alps. Geology, 43 (9), 815-818. https://doi.org/10.1130/G36833.1

Zhao, L., Paul, A., Malusà, M.G., Xu, X., Zheng, T., Solarino, S., Guillot, S., Schwartz, S., Dumont, T., Salimbeni, S., Aubert, C., Pondrelli, S., Wang, Q., \& Zhu, R. (2016). Continuity of the Alpine slab unraveled by high-resolution P wave tomography. Journal of Geophysical Research, 121. 8720-8737. https://doi.org/10.1002/2016JB013310

Zhao, L., Malusà, M. G., Yuan, H., Paul, A., Guillot, S., Lu, Y., Stehly, L., Solarino, S., Eva, E., Lu, G., Bodin, T., CIFALPS Group \& AlpArray Working Group (2020). Evidence for a serpentinized plate interface favouring continental subduction. Nature Communications, 11(1), 1-8. https://doi.org/10.1038/s41467-020-15904-7 